\title{
Development and basic evaluation of a prognostic aerosol scheme (v1) in the CNRM Climate Model CNRM-CM6
}

\author{
M. Michou, P. Nabat, and D. Saint-Martin \\ CNRM-GAME, Météo-France, Centre National de Recherches Météorologiques, UMR3589, 42 avenue G. Coriolis, \\ 31057 Toulouse CEDEX 1, France
}

Correspondence to: M. Michou (martine.michou@meteo.fr) and P. Nabat (pierre.nabat@meteo.fr)

Received: 12 August 2014 - Published in Geosci. Model Dev. Discuss.: 25 September 2014

Revised: 26 January 2015 - Accepted: 3 February 2015 - Published: 9 March 2015

\begin{abstract}
We have implemented a prognostic aerosol scheme (v1) in CNRM-CM6, the climate model of CNRMGAME and CERFACS, based upon the GEMS/MACC aerosol module of the ECMWF operational forecast model. This scheme describes the physical evolution of the five main types of aerosols, namely black carbon, organic matter, sulfate, desert dust and sea salt. In this work, we describe the characteristics of our implementation, for instance, taking into consideration a different dust scheme or boosting biomass burning emissions by a factor of 2 , as well as the evaluation performed on simulation output. The simulations consist of time slice simulations for 2004 conditions and transient runs over the 1993-2012 period, and are either free-running or nudged towards the ERA-Interim Reanalysis. Evaluation data sets include several satellite instrument AOD (aerosol optical depth) products (i.e., MODIS Aqua classic and Deep-Blue products, MISR and CALIOP products), as well as ground-based AERONET data and the derived AERONET climatology, MAC-v1. The uncertainty of aerosol-type seasonal AOD due to model internal variability is low over large parts of the globe, and the characteristics of a nudged simulation reflect those of a free-running simulation. In contrast, the impact of the new dust scheme is large, with modelled dust AODs from simulations with the new dust scheme close to observations. Overall patterns and seasonal cycles of the total AOD are well depicted with, however, a systematic low bias over oceans. The comparison to the fractional MAC-v1 AOD climatology shows disagreements mostly over continents, while that to AERONET sites outlines the capability of the model to reproduce monthly climatologies under very diverse dominant aerosol types. Here again, underestimation of the total AOD appears in sev-
\end{abstract}

eral cases, sometimes linked to insufficient efficiency of the aerosol transport away from the aerosol sources. Analysis of monthly time series at 166 AERONET sites shows, in general, correlation coefficients higher than 0.5 and lower model variance than observed. A large interannual variability can also be seen in the CALIOP vertical profiles over certain regions of the world. Overall, this prognostic aerosol scheme appears promising for aerosol-climate studies. There is room, however, for implementing more complex parameterisations in relation to aerosols.

\section{Introduction}

Tropospheric aerosols strongly influence the climate system (Kaufman et al., 2002) in multiple and complex ways because of interactions with radiation and clouds. They have been known, especially since the Third and Fourth IPCC (Intergovernmental Panel on Climate Change) Assessment Reports (Houghton et al., 2001; IPCC, 2007), and are still known to contribute strongly to the uncertainties in climate system modelling (see the Clouds and Aerosols chapter of the Fifth Assessment Report; Boucher et al., 2013) for several reasons such as, for instance, the quantification of aerosol-cloud effects (Lohmann et al., 2005), and the representation of their optical properties (Mallet et al., 2013) continues to be a challenge. A more basic uncertainty can be attributed to the inaccurate representation of the aerosol distribution in the atmosphere which is highly variable in space and time because of very diverse aerosol sources, themselves suffering from very different estimations (see e.g., de Leeuw et al., 2011) and of a lifetime shorter than a few days. This 
uneven distribution in the atmosphere remains hard to simulate with current climate models (Boucher et al., 2013).

Although a community of global aerosol modellers has been working together for more than 10 years under the AeroCom project (Aerosol Comparisons between Observations and Models), with coordinated simulation exercises analysed in a large number of papers (see Kinne et al., 2006, and Textor et al., 2006, as first papers, and http://aerocom.met.no for a list of publications), aerosol schemes within climate models, such as those used for phase 5 of the Coupled Model Intercomparison Project (CMIP5, Taylor, 2009), are still undergoing development and evaluation (see e.g., Evan et al., 2014). Modelling requires a fundamental understanding of processes and their representation in large-scale models, and a number of climate models continue to consider prescribed aerosol climatologies. Such climatologies have been continuously upgraded, from Tanré et al. (1984) to Kinne et al. (2013).

More recently, the ACCMIP (Atmospheric Chemistry and Climate Model Intercomparison Project; Lamarque et al., 2013) analysed the aerosol forcing of about 10 free-running global models, in contrast to AeroCom models driven by meteorological analyses, looking at past and future reference periods in coordination with CMIP5 experiments (Lee et al., 2013; Shindell et al., 2013). In general, these ACCMIP models have less sophisticated aerosol physics than the AeroCom models, and the issue of the added value of an explicit aerosol module as part of the climate model is still under debate (Ekman et al., 2014).

While Liu et al. (2012) present in their introduction a review of aerosol treatments in global climate models, from the bulk to the sectional methods, some of which treatments have been under development for a couple of decades, Flato et al. (2013) provide the references for the aerosol modules of the CMIP5 climate models (see Table 9.A.1).

We have implemented a prognostic aerosol module within the climate model of Météo-France that takes part in CMIP exercises in order to have the requisite tool to contribute to answering this issue. This tool will also improve our knowledge about aerosol-climate interactions. In this paper, we provide a description and an evaluation of this aerosol module. We describe the underlying general circulation model (GCM) and the aerosol scheme in Sect. 2, the simulations performed together with the evaluation data used in Sect. 3, and the results from our evaluation, with firstly intrinsic characteristics of our simulations, and then confrontation between simulation output and observed data sets in Sect. 4 .

\section{Description of the aerosol scheme}

\subsection{The underlaying GCM}

The aerosol scheme has been included as one of the physical packages of the ARPEGE-Climat GCM. ARPEGE-Climat is the atmospheric component of the CNRM-GAME (Centre National de Recherches Météorologiques - Groupe d'études de l'Atmosphère Météorologique) and CERFACS (Centre Européen de Recherche et de Formation Avancée) coupled atmosphere-ocean general circulation model (AOGCM) CNRM-CM, whose development started in the 1990s.

We present in this work an evaluation of the aerosol scheme driven by version 6.1 (v6.1) of ARPEGE-Climat which is an upgrade of v5.2, fully described in Voldoire et al. (2012), and used to contribute to CMIP5. ARPEGEClimat v6.1 is based on the dynamical core cycle 37 of the ARPEGE-Integrated Forecasting System (IFS), the operational numerical weather forecast models of Météo-France and the European Centre for Medium-Range Weather Forecasts (ECMWF). The major differences between v5.2 and v6.1 consist of differences in their respective physics: that of v5.2 is described in Voldoire et al. (2012), while the changes in v6.1 are in summary as follows: the vertical diffusion scheme is a prognostic turbulent kinetic energy scheme (Cuxart et al., 2000), where the microphysics is the detailed prognostic scheme of Lopez (2002), used both for the largescale and convective precipitation. The shallow and deep convection are those of the Prognostic Condensates Microphysics Transport (PCMT) scheme described in Piriou et al. (2007), and Guérémy (2011). Further details on ARPEGEClimat, valid for both versions 6.1 and 5.2, which concern, for instance, the radiation scheme appear in Voldoire et al. (2012). The surface parameters are computed by the surface scheme SURFEX (v7.3), already in place for CMIP5 simulations. SURFEX can consider a diversity of surface formulations for the evolution of four types of surface: nature, town, inland water and ocean. A description of SURFEX is available in the overview paper of Masson et al. (2013), from the simple to the quite complex parameterisations available. We considered for this paper a configuration of SURFEX very close to the one presented in Voldoire et al. (2012), except for the air-sea turbulent fluxes that are those of the COARE (Coupled Ocean-Atmosphere Response Experiment) 3.0 iterative algorithm (Fairall et al., 2003; Masson et al., 2013).

The interactive aerosol scheme presented below is aimed at replacing the description of the tropospheric aerosols currently in place in ARPEGE-Climat, which was used for the CMIP5 simulations and consists of 2-D monthly climatologies of the AOD (aerosol optical depth) of five types of aerosols, namely sea salt (SS), desert dust (DD), black carbon $(\mathrm{BC})$, organic matter $(\mathrm{OM})$ and sulfate $\left(\mathrm{SO}_{4}\right)$ aerosols, with a vertical profile depending on the aerosol type (see Voldoire et al., 2012).

The ARPEGE-Climat configuration used here is the one that CNRM and CERFACS scientists have agreed to probably serve as the basic configuration for future CMIP6 simulations: the ARPEGE-Climat spectral model is operated in a T127 triangular truncation, with the physics calculated to a N84 reduced Gaussian grid equivalent to a spatial resolution of about $1.4^{\circ}$ in both longitude and latitude. The vertical de- 
scription consists of 91 hybrid sigma pressure levels defined by the ECMWF, as already adopted in a number of studies with ARPEGE-Climat (e.g., Guérémy, 2011), which include 9 layers below $500 \mathrm{~m}$ and 52 layers below $100 \mathrm{hPa}$, ensuring a correct description of the vertical distribution of the tropospheric aerosols, from the surface with the aerosol emissions up to the middle troposphere where the concentration of most aerosols reach very low values. A time step of $15 \mathrm{~min}$ is used for the model integration.

\subsection{The original GEMS/MACC aerosol scheme}

The prognostic aerosol scheme of ARPEGE-Climat is based upon the GEMS/MACC (Global and regional Earth system Monitoring using Satellite and in situ data/Monitoring Atmospheric Composition and Climate) aerosol description included in the ARPEGE/IFS ECMWF operational forecast model starting in 2005 as part as the European project GEMS (2005-2009, Hollingsworth et al., 2008) and its follow-up projects MACC and MACC-II (2009, http://www.gmes-atmosphere.eu/), which provide a preoperational atmospheric environmental service to complement the weather analysis and forecasting services of European and national organisations by addressing the composition of the atmosphere.

The GEMS/MACC aerosol scheme describes the physical evolution of the five main types of tropospheric aerosols mentioned previously (Morcrette et al., 2009), in which various bins are considered: sea salt discriminates three particle size bins (boundaries of $0.03-0.5,0.5-5,5-20 \mu \mathrm{m})$, desert dust also has three size bins $(0.03-0.5,0.5-0.9,0.9-20 \mu \mathrm{m})$, and the boundaries given are for dry particles; however, the ambient humidity is taken into account in the computation of the aerosol optical properties. Organic matter and black carbon separate into a hydrophilic and a hydrophobic component and, for the representation of sulfate, both a gaseous sulfate precursor, mainly representing sulfur dioxide $\left(\mathrm{SO}_{2}\right)$, and sulfate aerosol $\left(\mathrm{SO}_{4}\right)$ are included. Hence the aerosol scheme adds 12 prognostic variables to the original prognostic meteorological variables. Large-scale and parameterized transport of the prognostic aerosols, e.g., convective and diffusive transport, are done in the same way as for any meteorological prognostic field (see Sect. 2.1).

A detailed description of the original GEMS/MACC aerosol scheme appears in Morcrette et al. (2009), and a list of parameters of the scheme, together with the values used for the MACC Reanalysis (see Sect. 3.2.1), is given in Table 1 . These parameters are fully detailed in Morcrette et al. (2009) and, for the sake of clarity, the parameter names in Table 1 correspond to the ones in Morcrette et al. (2009).

The scheme describes a number of physical aerosol processes, including dry deposition at the surface assuming constant dry deposition velocities depending on the aerosol bin and on the surface type (land, ocean, ice); sedimentation with a settling velocity depending on the aerosol bin; hygro- scopic growth or ageing of $\mathrm{OM}$ and $\mathrm{BC}$ is included using a constant conversion rate from the hydrophobic to the hydrophilic fractions (see Table 1) and assuming that OM is distributed between $50 \%$ hydrophilic and $50 \%$ hydrophobic when emitted, whereas BC is distributed between $80 \%$ hydrophilic and $20 \%$ hydrophobic when emitted; wet deposition in and below clouds, from large-scale and convective precipitation, with release of aerosols when precipitation reevaporates in the atmosphere; and conversion from $\mathrm{SO}_{4}$ precursors into $\mathrm{SO}_{4}$ that is done without explicit chemistry but is done assuming exponential decay, with a time constant depending on the latitude. Sources of SS and DD are calculated at each model integration using model meteorological fields. For SS, an emission flux is considered only over full ocean grids, and for their open ocean fraction only excluding a possible sea ice fraction, as a function of the wind speed at the lowest model level. The SS mass flux is tabulated depending on the wind speed class, based on work from Guelle et al. (2001) (see other references in Morcrette et al., 2009). For $\mathrm{DD}$, the parameterisation is derived from that of Ginoux et al. (2001). DD is produced over selected model grid cells, i.e., snow-free, fractions of bare soil/high and low vegetation above/below given thresholds, respectively, and depends on the soil upper layer wetness, the albedo, the model's lowest level wind speed and the particle radius. It is proportional to the dust emission potential (see Table 1), which is one of the terms of the source function of Morcrette et al. (2009). For the other aerosols, $\mathrm{OM}, \mathrm{BC}$ and the $\mathrm{SO}_{4}$ precursors, external monthly inventories are read in. The aerosol scheme separates between the biomass burning source, in order to allow for real-time updates of that source in the IFS model (see for instance Kaiser et al., 2012), and all the other sources (e.g., fossil fuel, natural sources). The inventories used for our simulations and for the MACC Reanalysis performed with the IFS system are presented, respectively, in Sects. 2.3.3 and 3.2.1.

Other papers related to this GEMS/MACC scheme address improvements of the scheme (Morcrette et al., 2008), the aerosol assimilation system fully integrated into the ECMWF assimilation apparatus (Benedetti et al., 2009), the Global Fire Assimilation System (GFAS) that calculates in real-time aerosol biomass burning emissions by assimilating observations from the MODIS (MODerate resolution Imaging Spectroradiometer) instruments (Kaiser et al., 2012), evaluation of all or individual aerosol distributions (Morcrette et al., 2009, 2011a, b; Huneeus et al., 2011; Mangold et al., 2011) and, finally, estimations of the GEMS/MACC aerosol radiative forcing (Bellouin et al., 2013). 


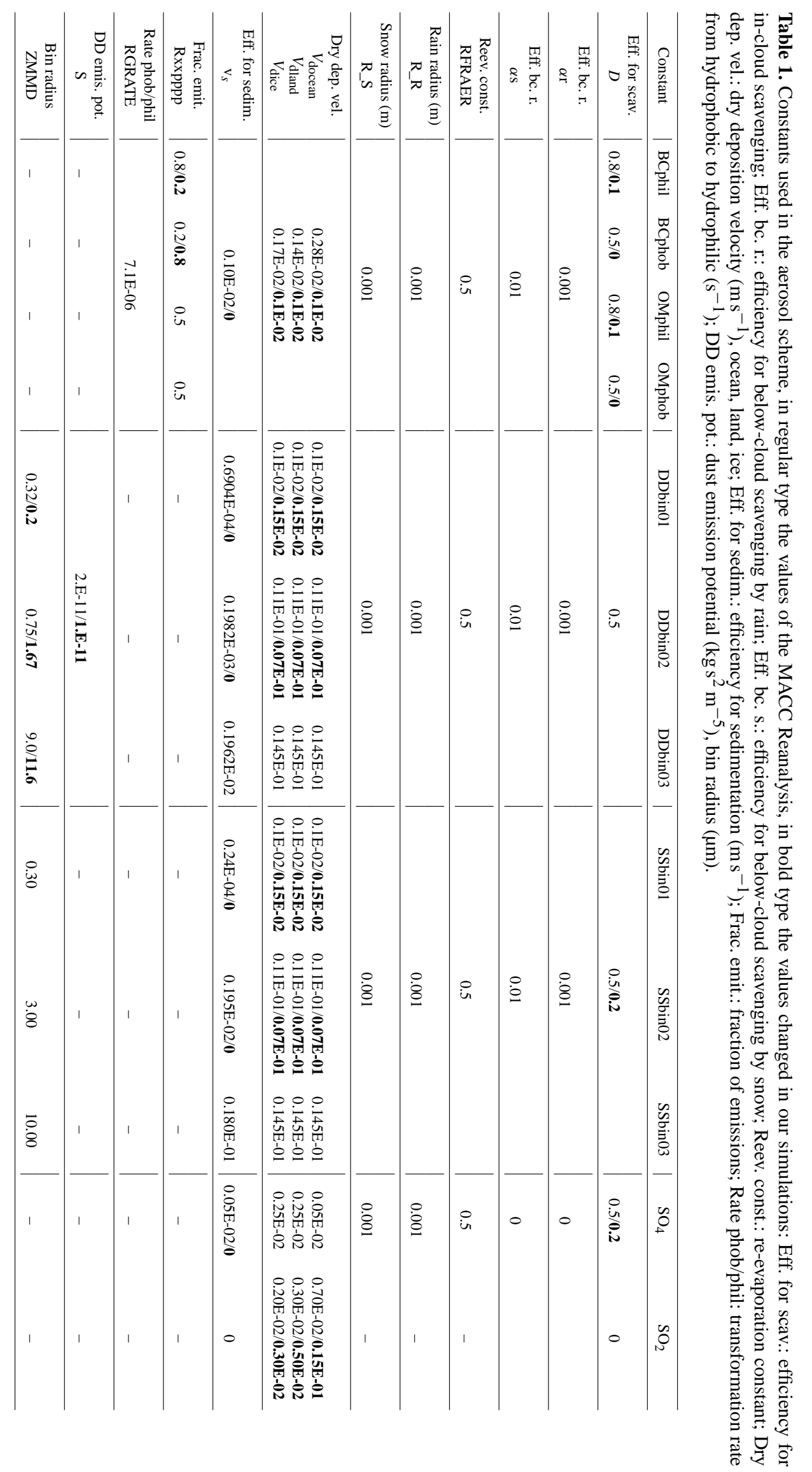




\subsection{Implementation of the aerosol scheme in ARPEGE-Climat}

\subsubsection{Adaptation of the scheme}

Preliminary simulations with the original configuration of the aerosol scheme, with the same prescribed emissions for $\mathrm{BC}$, $\mathrm{OM}$ and $\mathrm{SO}_{4}$ precursors as those for IFS runs, lead to aerosol concentrations much lower than the ones issued from IFS runs (not shown). As the literature presents a range of values for the various coefficients listed in Table 1, we adopted the values that would maximise the concentrations in ARPEGEClimat runs. These new values are shown in bold type in Table 1 . The efficiency of scavenging rates corresponds to the lowest values of Table 8 in Textor et al. (2006), whereas we got the deposition velocities from Huneeus (2007) and Reddy et al. (2005) and the settling sedimentation velocities from Huneeus (2007). One has to note that in this newer version of the aerosol scheme, the sedimentation process is applied only to the coarser bins of SS and DD, SSbin03 and DDbin03 in Table 1, as suggested in Huneeus et al. (2009). Additional information for sulfate and its precursors comes from Boucher et al. (2002). Lastly, the hydrophobic/hydrophilic fractions of emitted BC have been corrected from incorrect values, we now have fractions of $0.8 / 0.2$ in place of the original fractions of $0.2 / 0.8$, and the radii of the three dust bins have been modified (P. Nabat, personal communication, 2013), with $0.32-0.75-9.0 \mu \mathrm{m}$ and $0.2-1.67-11.6 \mu \mathrm{m}$ mean bin radii, respectively, in the GEMS/MACC and in our version (new bin boundaries of $0.01-1.0,1.0-2.5,2.5-20 \mu \mathrm{m}$ ). This size distribution adjustment was based on work done with the regional climate model RegCM (Zakey et al., 2006; Nabat et al., 2012); it has been recently validated in a regional version of CNRM-CM by Nabat et al. (2014b).

In addition to the adaptations presented above, developments have been made in the vertical diffusion and mass-flux convection schemes of ARPEGE-Climat (see Sect. 2.1) to account explicitly for the sub-grid transport of tracers.

\subsubsection{Inclusion of an additional dust scheme}

Dust aerosols simulated with ARPEGE-Climat and the dust scheme described in Sect. 2.2 confirmed the underestimation of dust aerosols already outlined by Melas et al. (2013) and Huneeus et al. (2011) when using a similar dust scheme within the IFS ECMWF model. This IFS dust scheme utilises spatially broad empirical factors developed at a time where the soil information required by other approaches was not available (Morcrette et al., 2009). Therefore, as a more complex scheme could be put into place in view of the detailed soil characteristic parameters available in ARPEGE-Climat from the ECOCLIMAP database (Masson et al., 2003), an additional dust emission parameterisation has been included in the aerosol scheme, allowing for comparisons between the two parameterisations. This dust emission parameterisation comes from Marticorena and Bergametti (1995), which is very common in aerosol global models, and takes into account soil information such as the erodible fraction and the fractions of sand and clay. The horizontal saltation flux is calculated as a function of the soil moisture, the surface roughness length and the wind velocity at the model's lowest level. The vertical flux is then inferred from this saltation flux, and the emitted dust size distribution is based on the work of Kok (2011) that corrects for a general drawback of GCMs to overestimate the mass fraction of the fine-mode dust while underestimating the fraction of coarser aerosol. More details about this dust emission parameterisation can be found in Nabat et al. (2012, 2014b). Note that the normalisation constant $c_{\alpha}$ proportional to the vertical to horizontal flux ratio (Nabat et al., 2012) had to be adjusted for the horizontal resolution of our simulations to a value of $c_{\alpha}=5 \times 10^{-7}$ to bring our 2004 AODs in the Sahelian region, the major global source of dust, into reasonable agreement with satellite and AERONET (AErosol RObotic NETwork) observations. Such adjustment is common in models (Todd et al., 2008), while some modelling groups even adopt scaling factors depending on the region (Tosca et al., 2013).

\subsubsection{Prescribed anthropogenic and natural emissions}

The basis for our prescribed emissions is the ACCMIP/AEROCOM emission inventory obtained from http:// accmip-emis.iek.fz-juelich.de/data/accmip/, fully presented and referred to as the A2-ACCMIP data set in Diehl et al. (2012), and used in other publications (e.g., Chin et al., 2014; Pan et al., 2014).

The A2-ACCMIP emissions are derived for $\mathrm{BC}$, primary organic carbon $(\mathrm{OC})$, and $\mathrm{SO}_{2}$, the major sulfate precursor, from the Lamarque et al. (2010) inventory developed for the IPCC Fifth Assessment Report. The original Lamarque et al. (2010) 1850-2000 inventory, from land-based anthropogenic sources and ocean-going vessels, in decadal increments, has been interpolated for A2-ACCMIP into yearly increments and extended beyond 2000 with the RCP8.5 (representative concentration pathways) future emission scenario (Riahi et al., 2011).

The A2-ACCMIP biomass burning emissions of BC, $\mathrm{OM}$ and $\mathrm{SO}_{2}$ are those of the ACCMIP/MACCity biomass burning data set, which contains monthly mean emissions with explicit interannual variability and which is the original data set used to construct the decadal mean ACCMIP biomass burning emissions (Granier et al., 2011). ACCMIP/AEROCOM emissions are originally at a $0.5^{\circ} \times 0.5^{\circ}$ resolution.

Natural emissions of aerosols include sulfur contributions from volcanoes and oceans (Boucher et al., 2002; Huneeus, 2007), and secondary organic aerosols (SOA) formed from natural volatile organic compound (VOC) emissions. We considered the $\mathrm{SO}_{2}$ from volcanoes described in Andres and Kasgnoc (1998), which is a yearly climatology of both con- 
tinuous degassing and explosive volcanoes $\left(1^{\circ}\right.$ horizontal resolution). The Kettle et al. (1999) dimethylsulfide (DMS) climatology, emitted from the oceans, is a monthly, $1^{\circ}$ horizontal data set and is therefore independent from the surface meteorological conditions in our simulations. A review of DMS inventories, available from http://www.geiacenter.org/ access/geia-originals, indicates that the Kettle et al. (1999) data set served as the basis for other DMS inventories and is still a valid data set to use. And finally, as our emission scheme does not describe the SOA formation, we prescribed the SOA inventory of Dentener et al. (2006), representative of the year 2000. Therefore, all three data sets, $\mathrm{SO}_{2}$ from volcanoes, DMS and SOA, do not have any interannual variability.

As in Boucher et al. (2002), and Huneeus (2007), we added an $\mathrm{H}_{2} \mathrm{~S}$ source as an additional sulfate precursor, which we scaled to the $\mathrm{SO}_{2}$ anthropogenic source (5\%), and we included a direct emission of sulfate $(5 \%$ of the emitted $\mathrm{SO}_{2}$; Benkovitz et al., 1996). In summary, our model adds $\mathrm{SO}_{2}$, DMS and $\mathrm{H}_{2} \mathrm{~S}$ emissions in our so-called sulfate precursor.

As preliminary simulations of $\mathrm{BC}$ and $\mathrm{OM}$ revealed that our model-related AODs were biased low - and keeping in mind a possible overestimation of our aerosol sinks noting that this option was qualified as "unlikely-but possible-" by Kaiser et al. (2012), who also worked with the Morcrette et al. (2009) model - we chose to augment our emissions by applying scaling factors to them. This appears to be quite a common practice in the aerosol modelling community, e.g., for BC and OM see Kaiser et al. (2012), and Tosca et al. (2013), and for SOA see Tsigaridis et al. (2014). Noting that a factor of 1.5 exists between OC emissions, as provided in the Juelich data set, and OM emissions (see Kaiser et al., 2012, and Chin et al., 2014, and references therein), we present results in this paper having applied a factor of 2 to the original Juelich BC and OM biomass burning emissions, and to the Dentener et al. (2006) SOA inventory. We computed this scaling factor from MISR (Multiangle Imaging Spectroradiometer) and MODIS observations over the two major biomass burning regions of South America and southern Africa to bring our 2004 AODs into reasonable agreement with the satellite data. Note that, unlike in Tosca et al. (2013), we did not apply factors depending on the region.

The emissions are injected into the surface layer of ARPEGE-Climat, which is about $20 \mathrm{~m}$ thick in our 91-level configuration, and quickly distributed throughout the boundary layer by model processes such as convection and vertical diffusion. We limited the $\mathrm{OM}$ surface emissions to $5 \times 10^{-9} \mathrm{~kg} \mathrm{~m}^{-2} \mathrm{~s}^{-1}$ and the $\mathrm{BC}$ and $\mathrm{SO}_{2}$ emissions to $5 \times$ $10^{-10} \mathrm{~kg} \mathrm{~m}^{-2} \mathrm{~s}^{-1}$ as higher values, reached very occasionally in space and time during very intensive biomass burning events or volcanic eruptions, generated unrealistic high AOD (higher than 10) in the model. The impact of this limitation on the monthly or yearly total emissions, and on most biomass burning events, is very small.
The resulting yearly totals emitted appear in Table 2, distinguishing the biomass burning, the natural and the other sources. Total emissions are higher in our simulations than in the MACC Reanalysis (see further details on the MACC Reanalysis emissions in Sect. 3.2.1) for all aerosols, but all our totals are within the ranges provided in the literature (see also Table 2). A significant part of the intra- and interannual variabilities comes from the biomass burning emissions (not shown), with the biomass burning sources representing 49 , 54 , and $3 \%$ of the total sources for BC, OM, and sulfate precursor emissions, respectively, in 2004, which is the reference year chosen for four of our simulations (see Sect. 3.1).

\section{Simulations performed and evaluation data used}

\subsection{Simulations}

The simulations performed (see Table 3 for a summary) include firstly an ARPEGE-Climat simulation with 2004 conditions for all forcings, namely SST (sea surface temperature), GHG (greenhouse gases) and climatologies of aerosols. This climatology of aerosols is the one that interacts with the radiation scheme of ARPEGE-Climat, as in the CMIP5 simulations (see Voldoire et al., 2012, and Szopa et al., 2012), and such a configuration allows for an evaluation of the prognostic aerosol distribution independently from their possible impact on the meteorology. This simulation, referred as the FreSim simulation, has been repeated over 10 years to account for the internal variability of the climate model. A second simulation consists of a nudged ARPEGE-Climat simulation, with spectral nudging (see Douville, 2009) of wind, temperature, humidity and surface pressure applied every $6 \mathrm{~h}$ towards the year 2004 of the ERA-Interim Reanalysis (Dee et al., 2011). The motivation for this nudged simulation is twofold: first, the nudging towards a meteorological reanalysis ensures that the simulated large-scale circulation is close to the observations and thus modelled aerosols are most realistic (Zhang et al., 2011). Second, comparing our free-running and nudged simulations will allow estimating some possible weaknesses of the free-running simulations. In this simulation, which is called NudSim, nudging is applied to the entire atmosphere and all model levels, with a transition zone from the surface over the last five model levels, the nudging strength being fixed at a $6 \mathrm{~h}$ e-folding time. Whether or not the humidity is nudged led to quite different aerosol distributions; we present here results where nudging of the humidity is applied. Two other simulations, i.e., FreSimd2 and NudSimd2 are identical to FreSim and NudSim except for the dust scheme, which is the one described in Sect. 2.3.2. Lastly, two transient simulations with corresponding transient forcings, FreSimd2_Trans and NudSimd2_Trans, have been performed with the dust scheme of Sect. 2.3.2 over the 1993-2012 period. This period covers the years of the MACC Reanalysis as well as 
Table 2. Prescribed emission totals, including those used for the 2004 simulations, the 2003-2012 transient simulations, the MACC Reanalysis, and totals reported in the literature.

\begin{tabular}{|c|c|c|c|c|c|}
\hline Sim./Litt. & & $\begin{array}{l}\text { Sim. } \\
2004\end{array}$ & $\begin{array}{r}\text { Sim. } \\
1993-2012\end{array}$ & $\begin{array}{r}\text { MACC Rean. } \\
2004\end{array}$ & Literature \\
\hline Species & Source & & & & \\
\hline \multirow[t]{3}{*}{$\mathrm{BC}$} & Tot. Sour. & 10.3 & $9.3-11.6$ & 6.2 & $12 \pm 3^{\mathrm{a}}, 15 \pm 14^{\mathrm{b}}$ \\
\hline & Bio. Burn. & 5.0 & $4.0-6.5$ & & \\
\hline & Oth. Sour. & 5.3 & $5.0-5.3$ & & $3.6-6.0^{\mathrm{d}}$ \\
\hline \multirow[t]{4}{*}{$\mathrm{OM}$} & Tot. Sour. & 117.3 & $106.0-138.8$ & 48.5 & $97 \pm 25^{\mathrm{a}}, 119 \pm 111^{\mathrm{b}}$ \\
\hline & Bio. Burn. & 63.2 & $52.4-85.2$ & & \\
\hline & SOA & 34.7 & 34.7 & & $19(13-121)^{\mathrm{c}}$ \\
\hline & Oth. Sour. & 19.4 & $18.3-19.5$ & & $9.5-23.0^{\mathrm{d}}$ \\
\hline \multirow[t]{3}{*}{$\mathrm{SO}_{2}$} & Bio. Burn. & 3.3 & $2.4-4.4$ & & \\
\hline & Volcan. & 14.7 & 14.7 & 0 & $29.2^{\mathrm{e}}$ \\
\hline & Oth. Sour. & 105.9 & $95.4-111.2$ & & $86.6-175.8^{\mathrm{d}}$ \\
\hline DMS & Oceans. & 39.8 & 39.8 & 0 & $20-80^{d}$ \\
\hline $\mathrm{H}_{2} \mathrm{~S}$ & Tot. Sour. & 5.3 & $4.8-5.6$ & 0 & \\
\hline $\mathrm{SO}_{4}$ & Tot. Sour. & 8.3 & $7.7-8.6$ & 0 & \\
\hline All $\mathrm{SO}_{4}$ prec. & Tot. Sour. & 177.2 & $166.0-182.9$ & 101.5 & $119 \pm 26^{\mathrm{a}}$ \\
\hline
\end{tabular}

the satellite and AERONET data used in our evaluation (see Sect. 3.2). NudSimd2_Trans has been nudged towards the ERA-Interim Reanalysis of 1993-2012 as with NudSim.

Another difference between the free-running and the nudged ARPEGE-Climat simulations, apart from their specific meteorology, is that release of aerosols in the case of stratiform precipitation re-evaporation is not applied to the free-running simulations. Such a release led to a limited number of abnormally high AODs, which was sufficient to perturb local AODs during a couple of weeks. This issue is not caused by the wet deposition formulation itself but appears to be linked to the characteristics of specific meteorological conditions along the vertical axis, which we do not encounter in the nudged simulations.

\subsection{Evaluation data}

\subsubsection{The MACC Reanalysis data}

The MACC Reanalysis, as part as the MACC FP-7 project is a 10-year long reanalysis of chemically reactive gases and aerosols using a global model and a data assimilation system based on the ECMWF IFS (see Inness et al., 2013). Its aerosol scheme is that described in Morcrette et al. (2009), so it is similar to the scheme evaluated here and its aerosol assimilation system uses MODIS AOD (Benedetti et al., 2009). Anthropogenic aerosol emissions are described in Granier et al. (2011), while the biomass burning emissions take advan- tage of the GFAS of MACC that rests upon daily fire radiative power information from the MODIS instruments (Kaiser et al., 2012; Inness et al., 2013). The MACC Reanalysis used, as we did, the SOA climatology of Dentener et al. (2006), but did not consider any sulfur emissions from volcanoes or oceans, and no direct sulfate emissions.

The MACC Reanalysis was performed onto 60 vertical hybrid sigma-pressure levels, with a model top at $0.1 \mathrm{hPa}$, and a T255 spectral truncation corresponding to a reduced N128 Gaussian grid with a horizontal resolution of approximately $80 \mathrm{~km}\left(0.7^{\circ}\right)$. Analyses of the characteristics of the simulated aerosols during this 10-year MACC Reanalysis appear in various papers including those of Bellouin et al. (2013), Melas et al. (2013), Nabat et al. (2013), and Cesnulyte et al. (2014).

\subsubsection{Satellite and ground-based data}

We used several observation data sets that complement each other. The satellite data were obtained from the NASA Langley Research Center Atmospheric Science Data Center, and consist firstly of the MODIS on board the Aqua satellite, which is widely used in the modelling aerosol community. We used the monthly product of total AOD at $550 \mathrm{~nm}$ over the 10-year period 2003-2012 (see Tanré et al., 1997, and Levy et al., 2007) at $1^{\circ}$ resolution, and the similar product derived from the Deep Blue algorithm developed to get aerosol optical thickness over bright land areas (Hsu et al., 2004). In addition, as there exist a variety of satellite aerosol prod- 
Table 3. Summary of ARPEGE-Climat simulations performed.

\begin{tabular}{lrrr}
\hline Name & Forcing & $\begin{array}{r}\text { Duration } \\
\text { (years) }\end{array}$ & Dust emission scheme \\
\hline FreSim & 2004 & 10 & Ginoux et al. (2001) \\
NudSim & 2004 & 1 & Ginoux et al. (2001) \\
FreSimd2 & 2004 & 10 & Marticorena and Bergametti (1995) \\
Kok (2011) \\
NudSimd2 & 2004 & 1 & Marticorena and Bergametti (1995) \\
Kok (2011) \\
FreSimd2_Trans & $1993-2012$ & 20 & Marticorena and Bergametti (1995) \\
Kok (2011) \\
NudSimd2_Trans & $1993-2012$ & 20 & Marticorena and Bergametti (1995) \\
& & & Kok (2011) \\
\hline
\end{tabular}

ucts that may disagree, as analysed for instance in Bréon et al. (2011) and Nabat et al. (2013), we included in our analysis AOD data from the MISR (Kahn et al., 2005, 2010) on board the Terra satellite. The MISR monthly product has the same horizontal resolution as MODIS and covers the period 2001-2012.

The Cloud-Aerosol Lidar with Orthogonal Polarization (CALIOP), on board the Aerosol Lidar and Infrared Pathfinder Satellite Observations (CALIPSO) satellite, is one of the very few satellite instruments providing vertical information on the aerosol distribution. We used a level-3 global monthly gridded 3-D CALIOP product that covers the years 2006-2011, already introduced at the end of the Koffi et al. (2012) paper, and under final evaluation (see Koffi in prep. and references therein). Extinction coefficients are provided at various wavelengths, under clear sky and all sky conditions, on a $1^{\circ}$ resolution grid, every $100 \mathrm{~m}$ from the surface up to $10 \mathrm{~km}$, for all aerosols and also distinguishing the dust component. We made analysis with the $532 \mathrm{~nm}$ products, in all sky conditions as Koffi et al. (2012) indicates that "the climatology of the mean aerosol vertical extinction distribution is not significantly affected by the presence of clouds."

AERONET is a ground-based globally distributed network of automatic sun photometer measurements of aerosol optical properties every $15 \mathrm{~min}$, which is a reference for AOD measurements (see Holben et al., 1998). For the present work, we used AOD monthly average quality-assured data (Level 2.0, see Holben et al., 2006) downloaded from the AERONET website (http://aeronet.gsfc.nasa.gov). Multiannual monthly averages are available from 1993, and we retained in our analysis stations that included 5 years, or more, of total AOD at various spectral bands, from which we recomputed the total AOD at $550 \mathrm{~nm}$ when missing in the original data set, using the Ångström coefficient. AERONET AOD data have a high accuracy of $<0.01$ for wavelengths longer than $440 \mathrm{~nm}$ and $<0.02$ for shorter wavelengths (Holben et al., 1998). We derived monthly time series and a representative station climatology from 166 AERONET stations over the world that represent areas under the influence of various dominant aerosols.

The EBAS is a database infrastructure (see http://ebas. nilu.no) operated by NILU - the Norwegian Institute for Air Research - that handles, stores and disseminates atmospheric composition data generated by international and national frameworks like long-term monitoring programmes, including IMPROVE (United States Interagency Monitoring of Protected Visual Environments) and EMEP (European Monitoring and Evaluation Programme), and research projects. For this article we downloaded and processed surface concentrations of $\mathrm{SO}_{2}$ and sulfate. These data, depending on the network, include daily or weekly values and for the EMEP or IMPROVE networks, which provided most of the data we used, are representative of areas away from the sources. We present in this article annual means (for 2005) from all observations available.

The Max Planck Institute Aerosol Climatology (MACv1) AEROCOM/AERONET monthly product of aerosol optical properties takes advantage of developments in aerosol modelling and in aerosol observational capabilities. It relies on information provided by the global network of groundbased sun photometers, mostly from the AERONET network (see above), together with an ensemble of model output of the AEROCOM experiments. The climatology includes estimates from pre-industrial (1860) to 2100 conditions and distinguishes between fine- and coarse-mode aerosols, the former with a radius from 0.05 to $0.5 \mu \mathrm{m}$ that mostly include particles produced by gas to particle conversion, while the latter, with a radius of up to $15 \mu \mathrm{m}$, include essentially sea salt and lifted soil-dust aerosols. It includes monthly data with global coverage at a spatial resolution of $1^{\circ}$. Temporal evolution distinguishes between anthropogenic aerosols that include interannual changes while natural aerosols consider only seasonal variations. For further details see Kinne et al. (2013). 


\section{Results}

\subsection{Some characteristics of the ARPEGE-Climat simulations}

\subsubsection{Internal variability}

As a preliminary step, we looked at the stability over time of the aerosol scheme. Figure 1 shows time series of global monthly mean concentrations, in the $1000-500 \mathrm{hPa}$ layer, of the 12 prognostic aerosol bins over a period common to the MACC Reanalysis and our transient simulations (20032012). Aside from these multi-year simulations, the diagrams include pseudo time series of the FreSim simulation that repeated 10 times the 2004 conditions.

Overall, all simulations, both nudged or free-running, show no drift over time of the aerosol concentrations. Starting with an initial state with no prognostic aerosols, equilibrium of aerosol concentrations is reached in ARPEGEClimat simulations within the period of a month (not shown).

Figure 2 displays the interannual standard deviation (SD) of the AOD (total and five main aerosols) for JJA (June-JulyAugust) and the FreSimd2 simulation. This SD is a representation of the internal variability in ARPEGE-Climat; moreover, we present this simulation and this season, as the SD for the FreSim simulation has similar characteristics to those of the FreSimd2 simulation, and as the variability in the model for the DJF (December-January-February) season is lower for all aerosols than that for the JJA season.

SDs $>0.01$ are always under $20-30 \%$ of the corresponding mean value, for all aerosols (not shown). Standard deviation of the total AOD is rarely higher than 0.05 , with the highest values in the biomass burning regions of central South America (SAM), southern Africa (SAF), and west of India (IND), which corresponds with larger SDs for OM and DD, respectively (see Fig. 2). Further insight into the internal variability of ARPEGE-Climat total AOD is provided with figures of vertical profiles of extinction coefficients for total aerosols (see Figs. 16, 17) and for dust aerosols (see Fig. 18). A description and analysis of these figures appear in Sect. 4.2.3, but for the matter of interest in this paragraph we can say that larger SD in the SAF and SAM regions, related to the diverse spread of biomass burning aerosols (i.e., OM and $\mathrm{BC}$ ), and in the Indian region (IND) in conjunction with variability in wet scavenging, appear to be consigned to altitudes below 3-4 km. In contrast, the SD of extinction coefficients in the central Atlantic (CAT) region, fully explained by the values and spread in dust extinction coefficients (see Fig. 18), is quite large, up to $5 \mathrm{~km}$. Overall, the interannual $\mathrm{SD}$ of the FreSimd 2 simulation is lower, for all sub-regions of the globe and for both seasons, than that of the CALIOP extinction profile product.

Overall, we can conclude from this short analysis that the internal variability of ARPEGE-Climat has little impact on the seasonal climatology of the AODs considering both all or individual aerosols.

\subsubsection{The nudged versus free-running simulations}

As relative differences in AOD between nudged and freerunning simulations appear independent of the dust scheme (not shown), we will discuss results for the simulations with the new scheme only. Figure 1 is a first illustration of the relative behaviour of the nudged (blue lines) versus freerunning (green lines) simulations. Global monthly means of aerosol concentrations from these two types of simulations appear as distinct curves except for three bins, namely the hydrophobic $\mathrm{OM}$ and $\mathrm{BC}$, and the sulfate precursor. In the FreSimd2_Trans and NudSimd2_Trans simulations, these 3 bins share several common characteristics of their physical evolution including no wet scavenging, no sedimentation, a dry deposition independent from the meteorology, and the same prescribed emissions. The specific meteorologies of these two simulations, which govern sub-grid-scale and large-scale transport, appear then to have little impact on the global mean monthly concentrations of these three bins. For the other bins, values are in general higher for the nudged simulation, in agreement with lower wet scavenging due to lower precipitation (not shown), and to the release of aerosols in the case of re-evaporation of precipitation which is suppressed in the free-running simulation (see Sect. 3.1). Total AOD in a nudged simulation (2004) without the re-evaporation process is lower by up to $20 \%$ maximum over most of the globe (global means of -11.3 and $-13.2 \%$ in DJF and JJA, respectively). However, the case of sea salt, with global means lower for the NudSimd2_Trans simulation, illustrates the relative importance of the various sources and sinks: with both lower dynamical emissions for DD and SS in the nudged simulation (by about 8 and $14 \%$, respectively, see Table 5), DD concentrations are higher in the nudged simulation while SS concentrations are lower. An explanation for that, in addition to the intrinsic distributions of SS and DD, is the smaller importance of wet scavenging on total losses for SS than for DD with efficiencies for scavenging of, respectively, 0.2 and 0.5 (see Table 1).

Figure 3 displays differences in AOD between the NudSimd 2 and the FreSimd 2 simulations, for DJF and JJA of 2004. Over most of the globe, absolute differences in total AOD (first row of the figure) are lower than 0.05 in DJF and 0.1 in JJA. However, differences are higher than 0.2 in DJF over central Africa (CAF), and in JJA over the southern Sahelian region, the Indian Ocean and spots in biomass burning regions such as Indonesia. For the former, these absolute differences come from differences in the OM AOD (see second row) in relation to differences in precipitation patterns (not shown) that impact the wet scavenging in this region and season of large biomass burning, while for the latter differences in total AOD mimic those in DD AOD (see third row). 

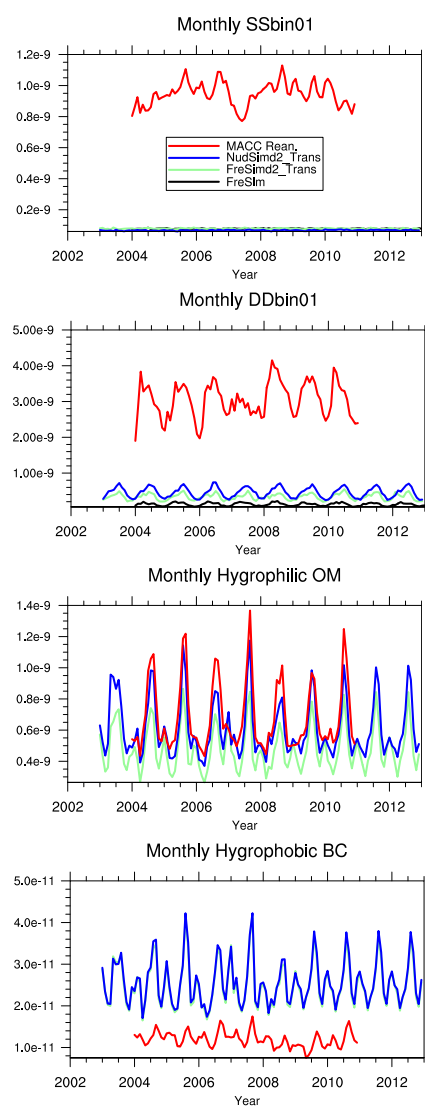
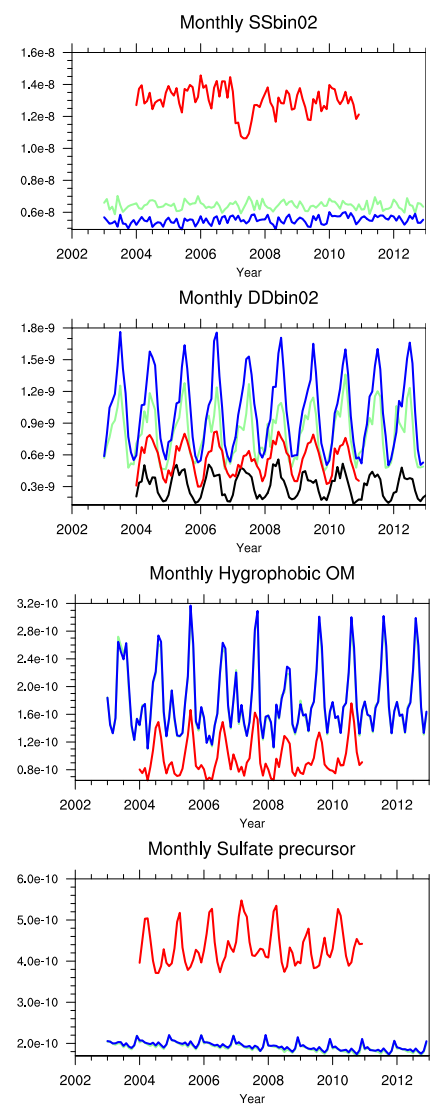
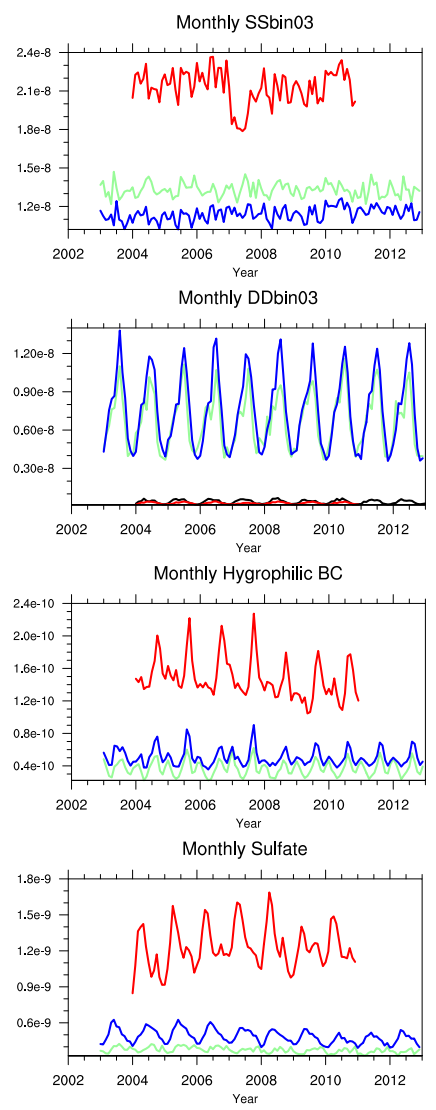

Figure 1. Time series of monthly mean global bin concentrations $\left(\mathrm{kg} \mathrm{kg}^{-1}\right)$ in the lower troposphere (1000-500 hPa layer) for the FreSimd2_Trans (green line), NudSimd2_Trans (blue line), and MACC Reanalysis (red line). In addition, dust bin concentrations are added for the FreSim simulation (black line, 2004 repeated 10 times). The 12 "bins" of the aerosol scheme are shown.

Further insight into the behaviour of both types of simulations is provided in Table 4, which shows global annual means of the burden, residence time and ratios of various sinks of the five aerosol types for the FreSimd2, NudSimd2, and MACC Reanalysis, while an estimation of the modelling range of these quantities is provided by Textor et al. (2006) and Huneeus et al. (2011). Burden and residence times are higher for the NudSimd2 than for the FreSimd2 simulation for all aerosol types except SS, which is coherent with the results of Fig. 1 previously analysed in this section. Values for both simulations are within the Textor et al. (2006), and Huneeus et al. (2011) mean $\pm 2 \sigma$ range, except in FreSimd2 for $\mathrm{SO}_{4}$ with too low burden and residence time, and in both simulations for SS with too large burdens. However, Grythe et al. (2014) report a spread of more than $70 \mathrm{Pg} \mathrm{yr}^{-1}$ in the "best" SS source functions studied, which would generate much higher burdens than those of Textor et al. (2006). While the dry dep. / wet dep. ratios are similar or lower for the FreSimd2 simulation than for the NudSimd 2 simulation, the conv. dep. / wet dep. ratios are about 2-3 times smaller for FreSimd2, and the wet dep. / total sink ratios a little larger for FreSimd2. Finally, the sed. dep. / dry dep. ratios, not null only for the coarser SS and DD bins, are the same for both simulations as dry deposition and sedimentation of large particles are independent from meteorology. In the end, more NudSimd2 results than FreSimd2 results shown in this table are closer to the AEROCOM means. Figures computed from the MACC Reanalysis diagnostics are also presented in Table 4 but should be taken as indicative only, as an error has been identified in the wet deposition amounts (up to $50 \%$ maximum), leading to an overestimation of the wet deposition diagnostics that results, for instance, in smaller MACC Reanalysis residence times. Apart from that error, MACC Reanalysis burden amounts appear too high for $\mathrm{SS}$ and $\mathrm{SO}_{4}$.

\subsubsection{Impact of the dust scheme}

Table 5 presents the mean annual dust emissions in various regions of the globe from our four simulations of year 2004 (see Table 3), the MACC Reanalysis, and the 15 AEROCOM global models analysed in Huneeus et al. (2011). The regions are also those of Huneeus et al. (2011). The AEROCOM range for the globe ( $\min$ and $\max$ ) is wide (i.e., 514-4313 $\mathrm{Tg} \mathrm{yr}^{-1}$ ), but while the FreSimd2 and NudSimd2 simulations fall within that range, the other two simulations, as well as the MACC Reanalysis, model lower emissions. To- 

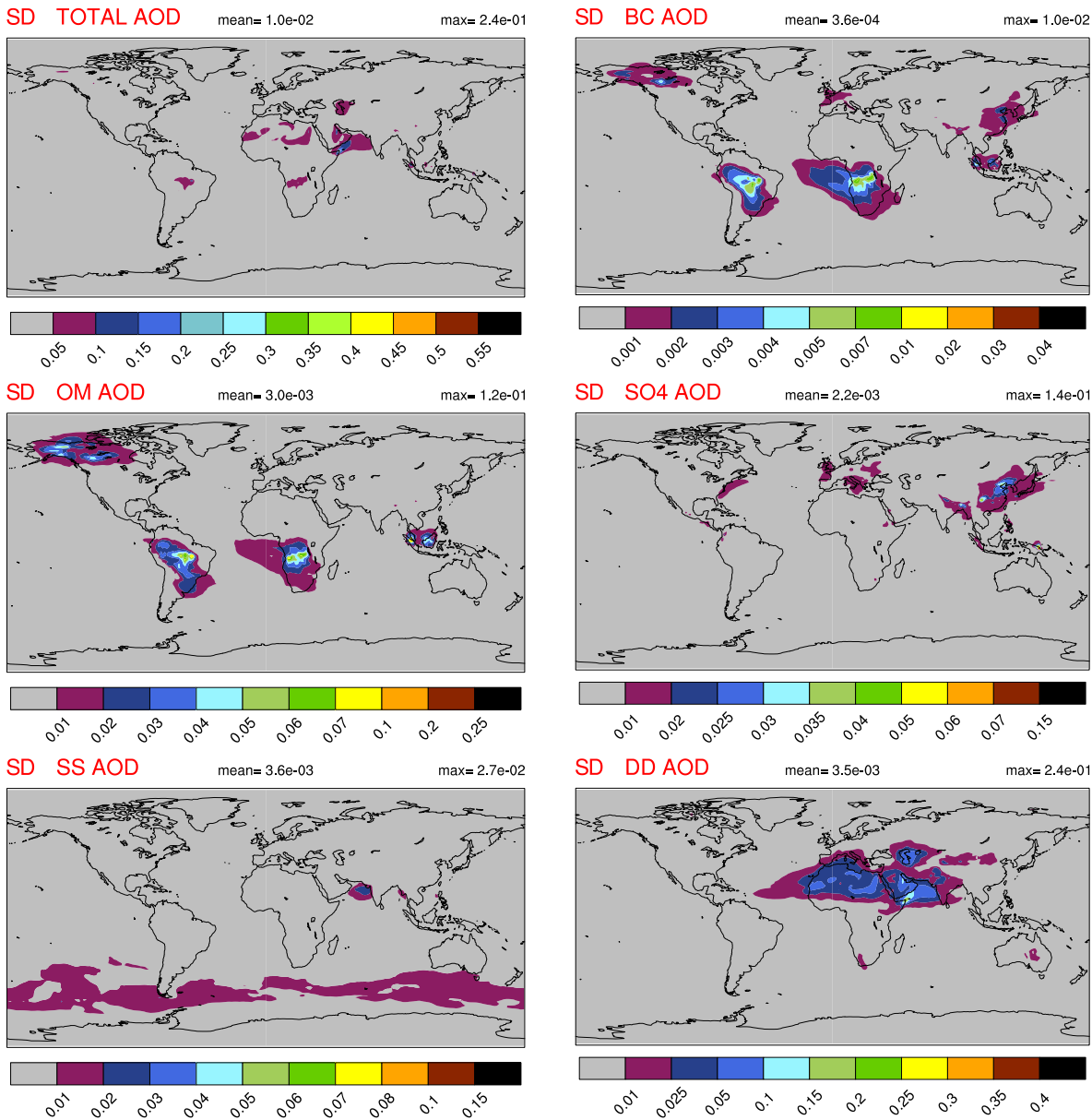

Figure 2. Mean standard deviation for JJA for the FreSimd2 simulation, as a representation of the ARPEGE-Climat internal variability, of the total, BC, OM, sulfate, SS, and DD AODs. Colour scales are the same as in Figs. 5 and 7.

tals in the regions may not have been consistently high (respectively low) within the same model, and our NudSimd2 simulation shows totals for the Middle East and Australia outside of the AEROCOM ranges, with particularly large emissions in Australia. This suggests that further adjustments of the scheme should be studied, and a simple adjustment could concern, for instance, the threshold of bare soil fraction within a grid cell required to trigger DD emissions. Such adjustments would depend on the underlying meteorology; the impact of the lowest level and surface meteorology is clearly seen with global emissions of the NudSimd 2 simulation being only about $92 \%$ of the corresponding simulation with ARPEGE-Climat meteorology (i.e., FreSimd2 simulation).

Total DD emissions are multiplied by a factor of 14 by this change of emission scheme (NudSim versus NudSimd2 simulation), knowing that factors are of 2.8, 2.9 and 20.9 for DDbin01, DDbin02 and DDbin03, respectively. These factors are large but we think that the Marticorena and Bergametti (1995) and Kok (2011) scheme is more realistic to use in the end, for the reasons detailed in Sect. 2.3.2. The corresponding changes in AOD, for the three dust bins and the total dust aerosol are shown in Fig. 4. The figure highlights also that the dust AOD pattern obtained with the new emission scheme is much more inhomogeneous than with the old scheme (this figure) and the MACC Reanalysis (Fig. 5). This is in better agreement with the satellite MISR and Deep Blue output (Figs. 6, 7), and it reflects the soil characteristics taken into account in the new dust scheme (see Sect. 2.3.2). In the end, the mean global total DD AOD is enhanced by 4.8 .

\subsubsection{ARPEGE-Climat simulations versus the MACC Reanalysis}

Evaluations of climate models against reanalysis output are very common practice. The MACC Reanalysis is all the more interesting to us as we make use of a twin aerosol scheme, and as we can access in the ECMWF MARS (Meteorological Archival and Retrieval System) archive diagnoses that are less common than the AODs, such as 3-D individual bin concentrations. Evaluation results about the MACC Reanalysis indicate that the MACC system generally provides a good representation of the AOD on a monthly basis (Cesnulyte et 

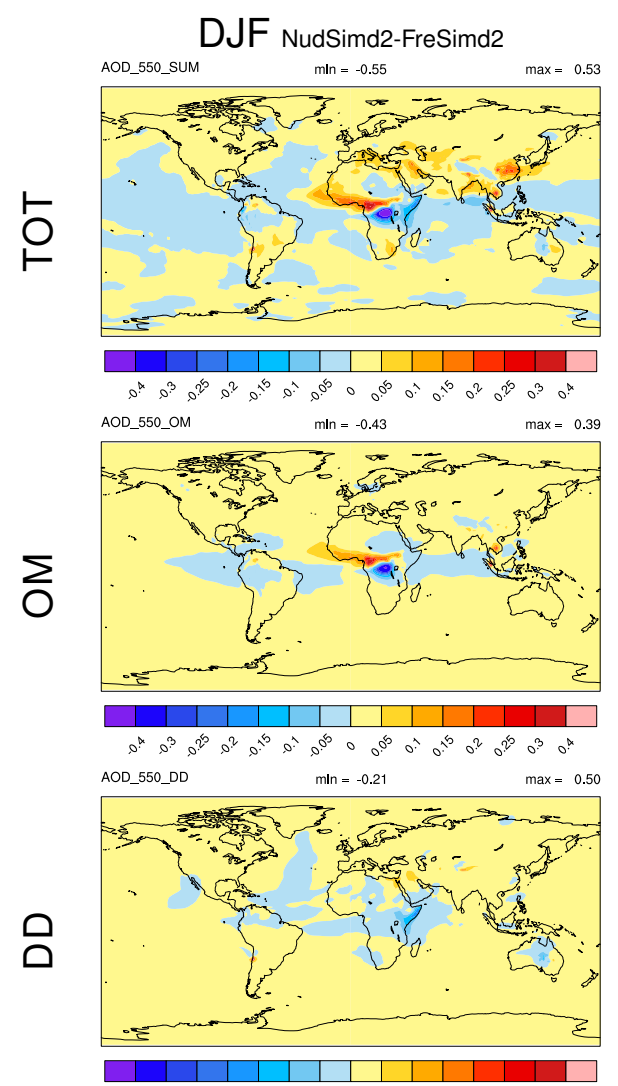

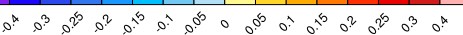
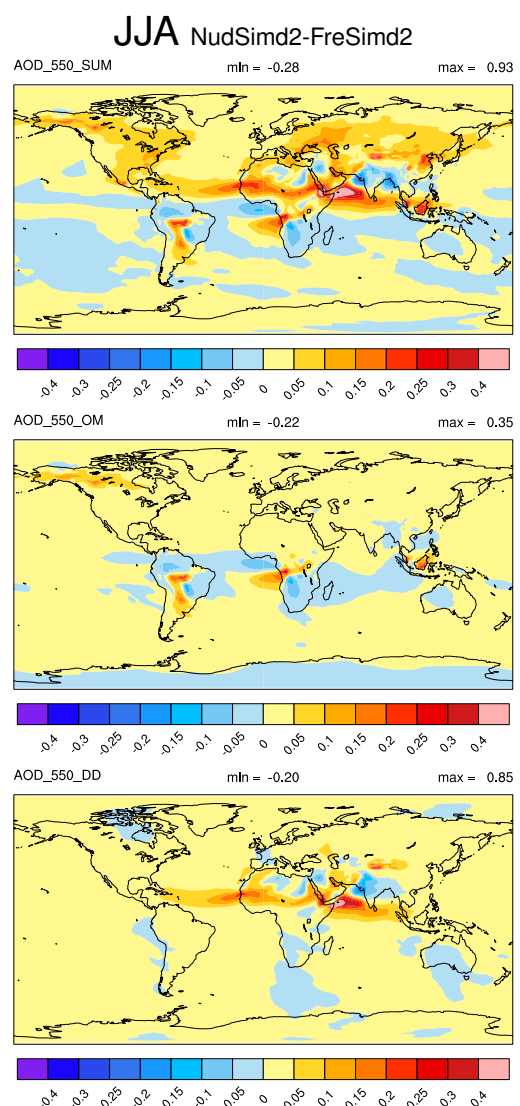

Figure 3. Differences in AOD between the NudSimd2 and the FreSimd2 simulations, for DJF (left column) and JJA (right column), and for total AOD (first row), OM AOD (second row) and DD AOD (last row).

al., 2014). However, a few deficiencies have been underlined (Melas et al., 2013), such as dust being associated with too small particles and, thus, being overly transported to regions very remote from the sources. Another deficiency is that sea salt seems to be overestimated and contributes to a high AOD bias in southern oceanic regions.

The results of the comparison between our model output and the MACC Reanalysis are the following, noting that BC comparisons between the MACC Reanalysis and our simulations cannot be fairly made as an unrealistic hydrophilic hydrophobic tion was assumed in the MACC Reanalysis (see Table 1).

Global means of tropospheric binned concentrations are shown in Fig. 1 for the MACC Reanalysis (red lines) and the NudSimd2_Trans simulation (blue lines). Concentrations of the various bins from our simulations are biased low compared to the MACC Reanalysis, except for the hydrophobic bins, this being possibly linked to the suppression of wet scavenging in our scheme (see Table 1), and, linked to our new dust scheme, for the two coarser dust bins. Modifications of the constants of the aerosol scheme to trigger higher concentrations (see Sect. 2.3.1), in parallel with enhancement of prescribed emissions (see emission totals in Table 2), re- sulted in these very different global monthly means. Differences in sea salt concentrations are particularly striking.

Analysis of global maps of AODs (see Fig. 5) reveals that transport away from the sources is more efficient with the MACC Reanalysis meteorology than with the meteorological conditions of our nudged simulation. In the end, lower global mean values of the NudSimd2_Trans simulation in Fig. 1 are caused by lower concentrations away from the source regions. This is the case for all smaller aerosols with no or little sedimentation, and is clearly visible for instance for $\mathrm{BC}, \mathrm{OM}$ and sulfate. In the case of SS, in addition to long-range transport characteristic of the MACC Reanalysis, concentrations or AODs are larger in the MACC Reanalysis even at the source regions with higher emissions (64.2 versus $51.6 \mathrm{Pg} \mathrm{yr}^{-1}$ ). However, as SS in the MACC Reanalysis seems to be overestimated (see above), we chose to go along in this paper with our modelled SS distributions.

Finally, these results can also be explained by the role of the aerosol assimilation present in the MACC Reanalysis that significantly modifies aerosol concentrations and improves agreement with observations as compared to control runs without aerosol assimilation (Kaiser et al., 2012; Melas et al., 2013). 


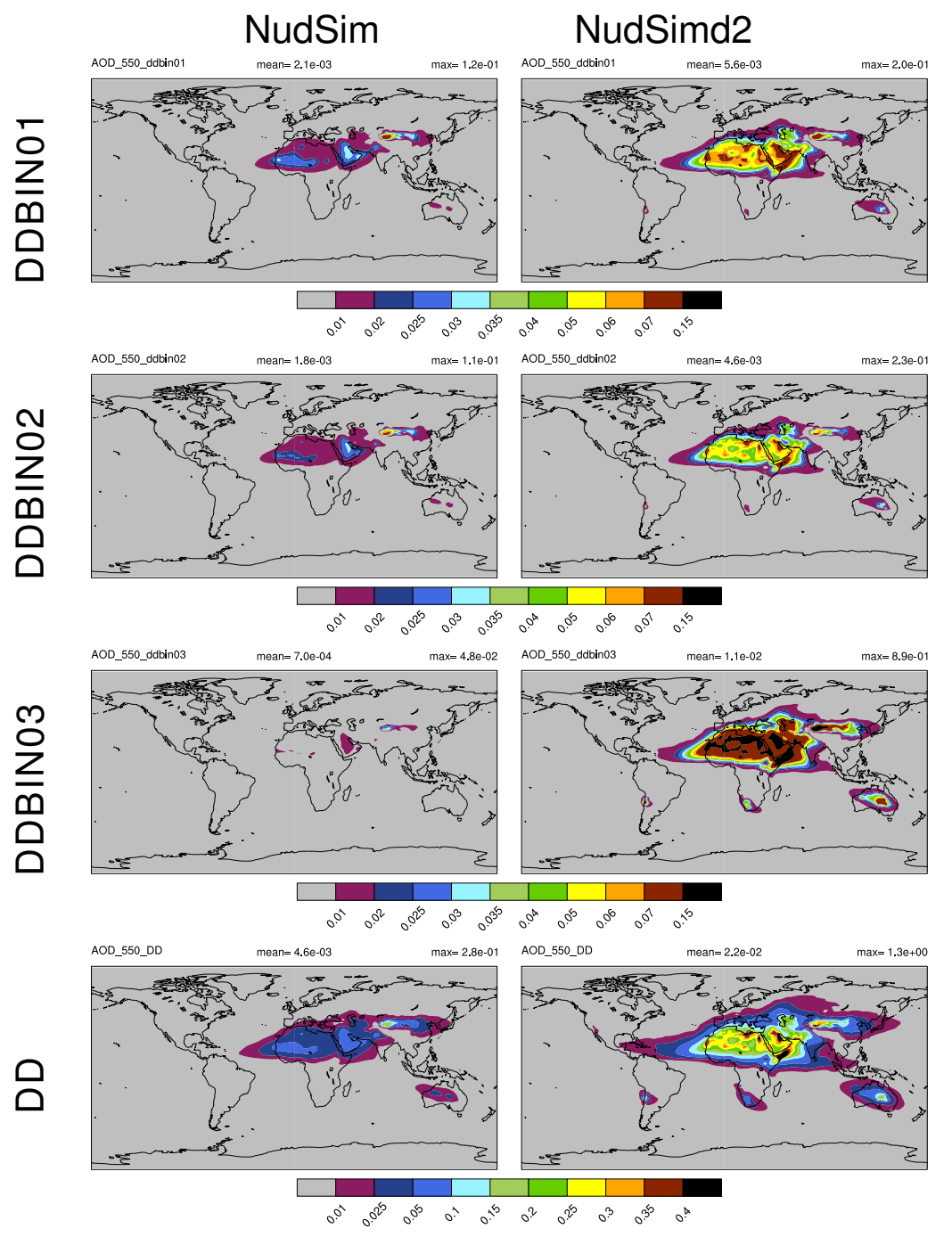

Figure 4. Mean 2004 dust AOD for the NudSim (first column), and the NudSimd2 (second column) simulations, for the three dust bins, from the smallest (first row) to the largest (third row), and total DD AOD (fourth row).

In summary, we demonstrated that (1) in a climatological perspective ARPEGE-Climat free-running and nudged simulations show little differences and (2) the new dust scheme performs much better than the original one, we will continue in the remainder of this paper with the analysis of the NudSimd2_Trans simulation only against observations.

\subsection{ARPEGE-Climat simulations versus satellite and ground-based data}

\subsubsection{Total AOD}

Figures of total AOD (Fig. 6 and following) show DJF and JJA means over 2003-2012 of the three satellite data sets, i.e., MODIS Aqua standard and Deep Blue products and MISR, of our NudSimd2_Trans simulation, and of the Kinne et al. (2013) climatology representative of the year 2000. The main spatial patterns as well as the local seasonal cycles of the total AOD in various regions of the globe, in conjunction for instance with JJA dust emissions in northern Africa or the Middle East, or biomass burning in central Africa, or sea salt production in the southern oceans, are clearly depicted by the model. However, overall, model output underestimates satellite observations, noting that the three satellite data sets may greatly disagree over large areas.

In the case of MISR, which has the largest spatial coverage of the satellite data we used, the model underestimation is lower in JJA than in DJF, with a mean relative bias of -41 and $-52 \%$, respectively (see Figs. 8, 9). This low bias is mainly driven by the oceanic values. In contrast, the model overestimates the observations in DJF in areas such as central Africa, parts of Saudi Arabia and northern Africa, or in JJA over the Arabian Sea or large parts of South America. Areas of model overestimation seem to follow the trace of 
Table 4. Burden, residence time and ratios for various sinks from the FreSimd 2 simulation (mean over the 10 repeated 2004 years), the NudSimd2 simulation (year 2004), the MACC Reanalysis (2003-2012 mean), and the AEROCOM models reported in Textor et al. (2006) (mean $\pm \sigma$, see Table 10).

\begin{tabular}{|c|c|c|c|c|c|c|c|c|}
\hline $\begin{array}{l}\text { Parameter } \\
\text { Simulation }\end{array}$ & $\begin{array}{l}\text { DD } \\
\text { FreSimd2 }\end{array}$ & NudSimd2 & MACC Rean. & AEROCOM & $\begin{array}{l}\text { SS } \\
\text { FreSimd2 }\end{array}$ & NudSimd2 & MACC Rean. & AEROCOM \\
\hline burden $(\mathrm{Tg})$ & 17.99 & 23.30 & 11.00 & $19.2 \pm 40 \%$ & 33.32 & 27.15 & 69.53 & $7.52 \pm 54 \%$ \\
\hline residence time (days) & 1.56 & 2.18 & 3.35 & $4.14 \pm 43 \%$ & 0.21 & 0.19 & 0.32 & $0.48 \pm 58 \%$ \\
\hline dry dep./wet dep. (\%) & 220.16 & 259.81 & 30.82 & $148 \pm 95 \% *$ & 163.30 & 163.17 & 102.99 & NA \\
\hline sed. dep./dry dep. (\%) & 13 & 13 & 7 & $46 \pm 66 \%$ & 90 & 90 & 92 & $59 \pm 65 \%$ \\
\hline conv. wet dep./wet dep. (\%) & 12 & 42 & 28 & $44 \pm 51 \%$ & 31 & 48 & 22 & $34 \pm 53 \%$ \\
\hline wet dep./total $\operatorname{sink}(\%)$ & 29 & 25 & 75 & $33 \pm 54 \%$ & 24 & 24 & 34 & $30 \pm 65 \%$ \\
\hline Parameter & $\mathrm{BC}$ & & & & $\mathrm{OM}$ & & & \\
\hline Model & FreSimd2 & NudSimd2 & MACC Rean. & AEROCOM & FreSimd 2 & NudSimd2 & MACC Rean. & AEROCOM \\
\hline burden (Tg) & 0.13 & 0.18 & 0.43 & $0.24 \pm 42 \%$ & 1.31 & 1.77 & 2.03 & $1.70 \pm 27 \%$ \\
\hline residence time (days) & 4.68 & 6.28 & 2.44 & $7.12 \pm 33 \%$ & 3.74 & 5.09 & 2.56 & $6.54 \pm 27 \%$ \\
\hline dry dep./wet dep. (\%) & 14.84 & 17.60 & 12.62 & NA & 28.83 & 31.01 & 15.91 & NA \\
\hline sed. dep./dry dep. (\%) & 0 & 0 & 53 & $0 \pm 251 \%$ & 0 & -0 & 55 & $1 \pm 198 \%$ \\
\hline conv. wet dep./wet dep. (\%) & 27 & 53 & 21 & $46 \pm 52 \%$ & 26 & 56 & 25 & $52 \pm 48 \%$ \\
\hline wet dep./total sink (\%) & 87 & 85 & 84 & $79 \pm 17 \%$ & 78 & 76 & 80 & $80 \pm 16 \%$ \\
\hline Parameter & $\mathrm{SO}_{4}$ & & & & & & & \\
\hline Model & FreSimd2 & NudSimd2 & MACC Rean. & AEROCOM & & & & \\
\hline burden $(\mathrm{Tg})$ & 0.92 & 1.30 & 3.35 & $1.99 \pm 25 \%$ & & & & \\
\hline residence time (days) & 2.25 & 3.18 & 2.27 & $4.12 \pm 18 \%$ & & & & \\
\hline dry dep./wet dep. (\%) & 15.46 & 18.70 & 7.95 & NA & & & & \\
\hline sed. dep./dry dep. (\%) & 0 & 0 & 73 & $7 \pm 202 \%$ & & & & \\
\hline conv. wet dep./wet dep. (\%) & 27 & 47 & 22 & $40 \pm 54 \%$ & & & & \\
\hline wet dep./total sink (\%) & 87 & 84 & 88 & $89 \pm 8 \%$ & & & & \\
\hline
\end{tabular}

${ }^{*}$ Huneeus et al. (2012) values. DD, SS, BC, $\mathrm{OM}$ and $\mathrm{SO}_{4}$ aerosols are presented.

Table 5. Upper part of the table: dust emissions $\left(\mathrm{Tg} \mathrm{yr}^{-1}\right)$ over regions defined in Huneeus et al. (2011), for the FreSim and FreSimd 2 simulations, the NudSim and NudSimd2 simulations (year 2004), the MACC Reanalysis (2003-2012 mean), and results from 15 AEROCOM models analysed in Huneeus et al. (2011), median, min, and max values. In italic font, totals lower than the AEROCOM min, in bold font, totals higher than the AEROCOM max. Lower part of the table: global sea salt emissions $\left(\mathrm{Pg} \mathrm{yr}^{-1}\right)$, with a range from Grythe et al. (2014).

\begin{tabular}{lrrrr}
\hline $\begin{array}{l}\text { Dust } \\
\text { Tg yr }\end{array}$-1 & FreSim/FreSimd2 & NudSim/NudSimd2 & MACC Rean. & $\begin{array}{r}\text { AEROCOM Median } \\
\text { (min-max })\end{array}$ \\
Region & & & 313 & $1123(514: 4313)$ \\
Global & $330 / 3916$ & $256 / 3597$ & 88 & $792(204: 2888)$ \\
North Africa & $98 / 1226$ & $66 / 1034$ & 37 & $128(26: 531)$ \\
Middle East & $59 / \mathbf{6 2 1}$ & $51 / \mathbf{5 7 2}$ & 75 & $137(27: 873)$ \\
Asia & $75 / 455$ & $61 / 405$ & 2 & $10(0: 186)$ \\
South America & $0 / 47$ & $0 / 48$ & 12 & $31(9: 57)$ \\
South Africa & $5 / 72$ & $3 / 51$ & 16 & $2(2: 286)$ \\
Australia & $31 / \mathbf{2 5 7}$ & $1 / 13$ & & Range Grythe et al. $(2014)$ \\
North America & $1 / 11$ & & NudSim & MACC Rean. \\
\hline Sea Salt & & 51.6 & 64.2 & 1.8 to 605.0 \\
Pg yr & FreSim & 59.9 & &
\end{tabular}

biomass burning in tropical regions, while dust appears overestimated over the Arabian Sea. Over continents in JJA, at mid to northern latitudes, the bias appears quite patchy, with both positive and negative values.
MISR and MODIS differ by more than $20 \%$ over large parts of the oceans, and they contrast even more over continents (not shown). The same comment applies to MODIS Deep Blue over continents, and is even more true for the 

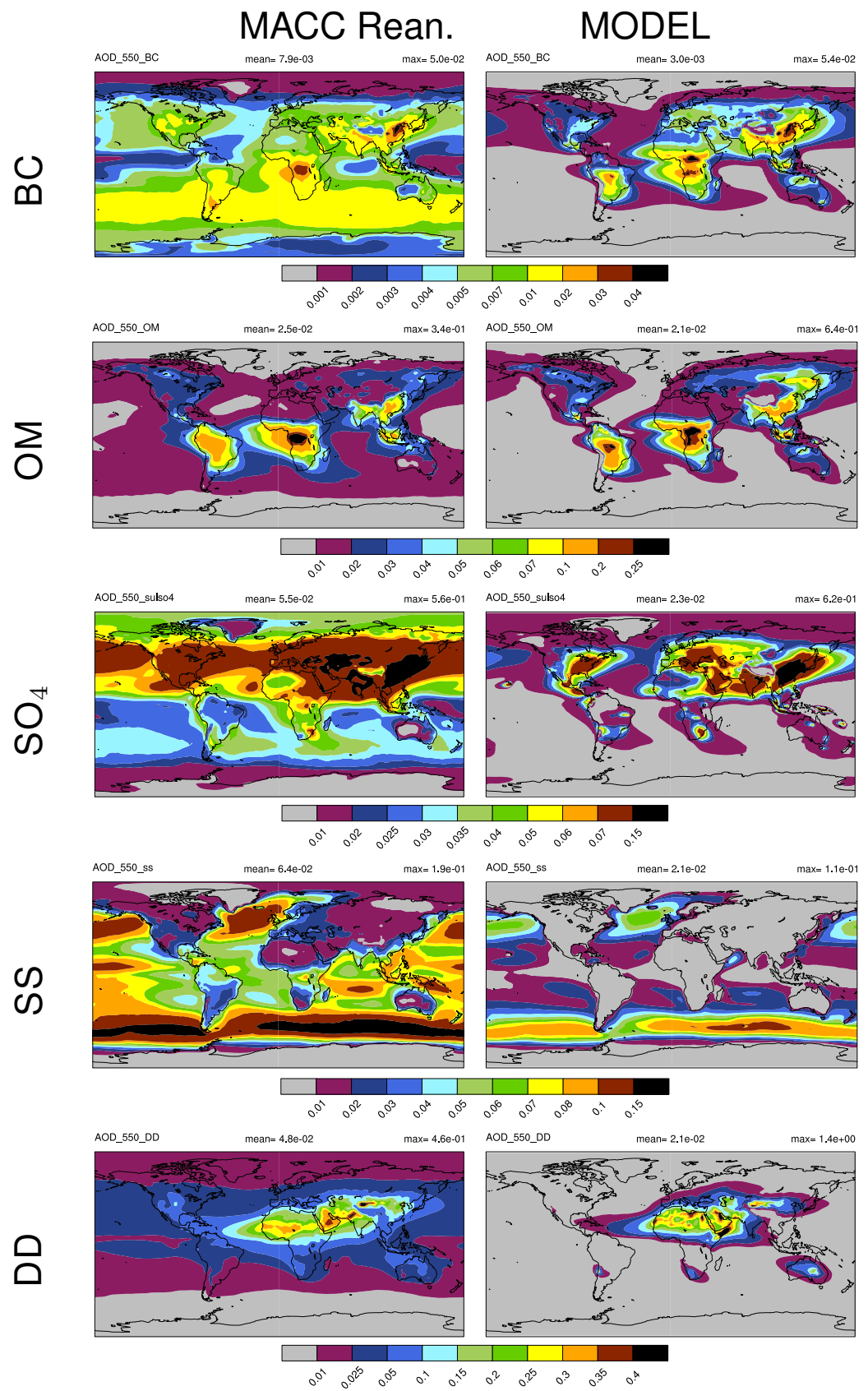

Figure 5. Mean AOD (2003-2012) for the MACC Reanalysis (first column), and the NudSimd2_Trans simulation (second column), for BC, OM, sulfate, SS and DD.

Kinne et al. (2013) climatology. As a consequence, relative biases between model output and the other two satellite data sets, i.e., the MODIS Aqua and the Deep Blue products, yielded different results; see Figs. 8 and 9. This is particularly the case over South America and Australia with large areas of observed low AODs (lower than 0.1). Over mid- to high-latitude oceans, the bias between Kinne et al. (2013) and our simulation is lower (around 10-50\%) than the bias between MISR and our simulation (around 30-70\%).

\subsubsection{Fractional AOD}

Figure 10 shows several fractions of the annual mean total AOD, for the Kinne et al. (2013) climatology, representative of the year 2000, and the NudSimd2_Trans simulation. The fractions are those available in Kinne et al. (2013) and we grouped our aerosol scheme bins to comply to the extent possible to these fractions. Total AOD has been separated in AOD from the coarse mode (the two largest of the three bins of SS and DD in our simulations, not shown), the fine mode, 


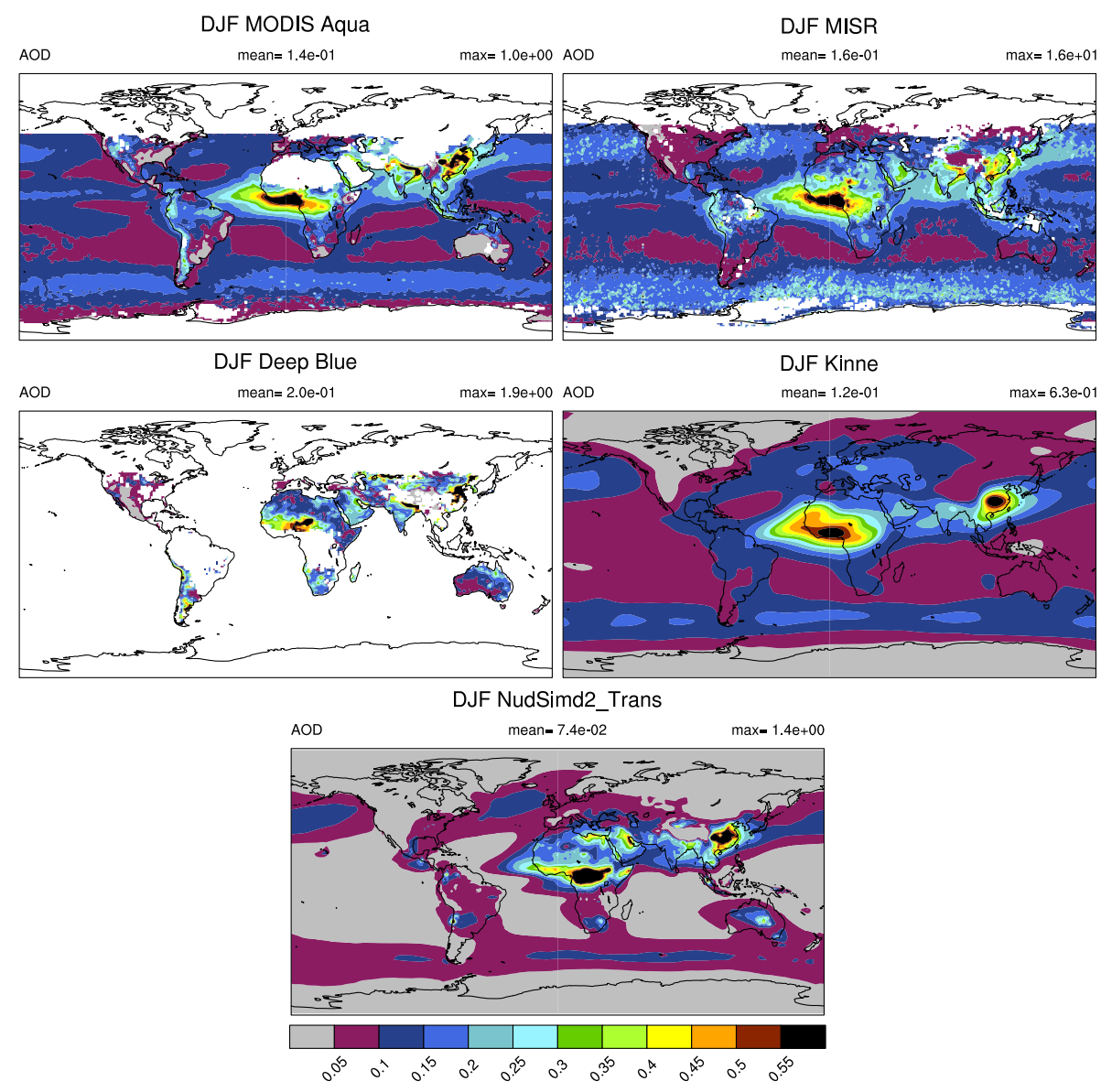

Figure 6. Mean DJF 2003-2012 total AOD for the MODIS Aqua, MISR, MODIS Deep-Blue and Kinne et al. (2013) data sets (from the top in the direction of reading), and from the NudSimd2_Trans simulation (third row).

which complements the coarse mode, the anthropogenic sulfate aerosols (in our case sulfate from all sources, including natural sources such as oceans or volcanoes), and the natural aerosols (in our case DD and SS aerosols). This grouping may not appear fully satisfactory, the anthropogenic sulfate aerosols would for instance have been best identified running a supplementary simulation with pre-industrial conditions (Schulz et al., 2006; Myhre et al., 2013) or applying more complex grouping methodologies such as in Bellouin et al. (2013), and Sessions et al. (2015), but the comparison detailed below is intended as a first estimation of our model output.

Higher coarse-mode AODs are associated with dust (e.g., northern Africa) and sea salt (e.g., Southern Ocean), whereas higher fine-mode AOD contributions are registered over regions of urban pollution and regions affected by biomass burning. As these two modes complement each other, a model underestimation of the former goes with a model overestimation of the latter and vice versa. In general, the model overestimates the fine-mode fraction over continents and at high latitudes (by $20 \%$ or more), except for the very northern part of Africa, the Mongolian desert region, and the trop- ical Pacific Ocean. The comparison is better for oceans, with large areas within $20 \%$ of the Kinne et al. (2013) climatology, the northern tropical Atlantic excepted.

The sulfate fractions of the total AODs of Kinne et al. (2013) and the NudSimd2_Trans simulation show similarities in their hemispheric repartition, with fractions lower than 0.3 in most of the Southern Hemisphere. Over Europe and the United States, however, our fractions appear too high (by $20-80 \%)$. This is also the case over regions in pristine air affected only by volcanoes, such as the Hawaiian Islands or the Antarctic continent (Mount Erebus volcano), which is coherent with the Kinne et al. (2013) sulfate fraction consisting of anthropogenic sulfate only.

Finally, the fraction of natural aerosols is correctly simulated over the oceans and dust-producing regions. Over the rest of the continents, we underestimate this fraction (by 60$90 \%$ ) as we could not include in this fraction the contribution from second organic aerosols, which is not a simulation output.

Figure 11, which compares observations and NudSimd2_Trans outputs of annual (2005) surface concentrations of $\mathrm{SO}_{2}$ and sulfate, provides additional information 


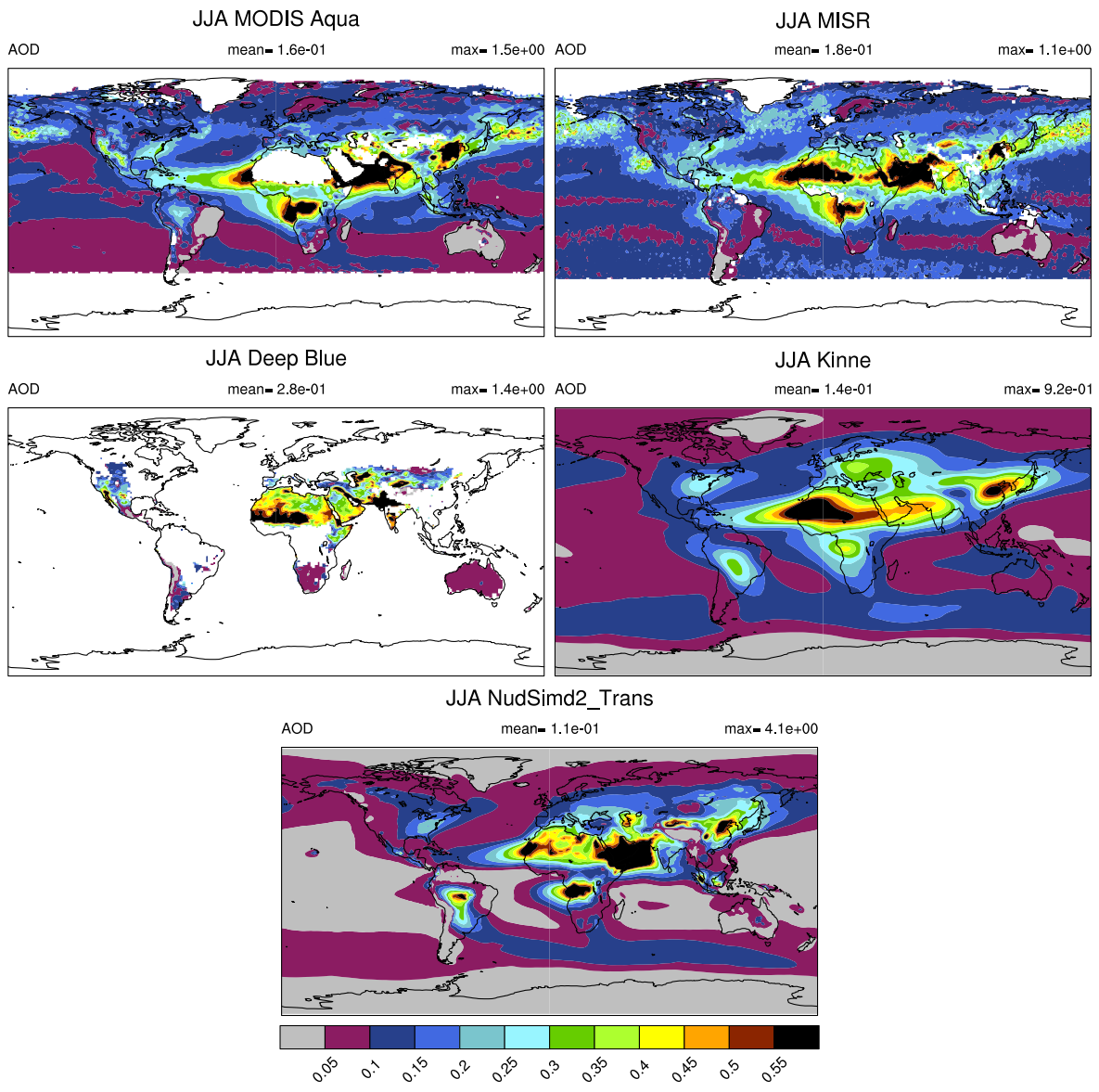

Figure 7. Same as Fig. 6, for JJA.

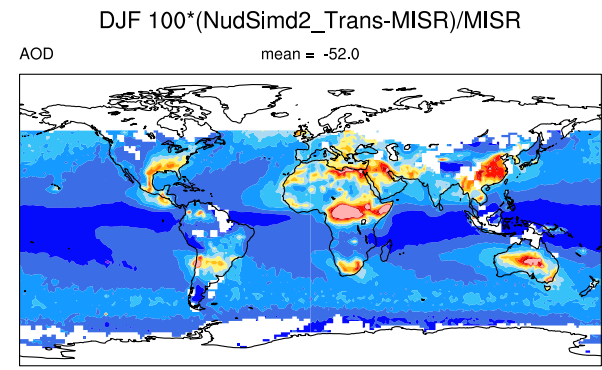

DJF 100*(NudSimd2_Trans-MODIS Aqua)/MODIS Aqua

DJF 100*(NudSimd2_Trans-Deep Blue)/Deep Blue
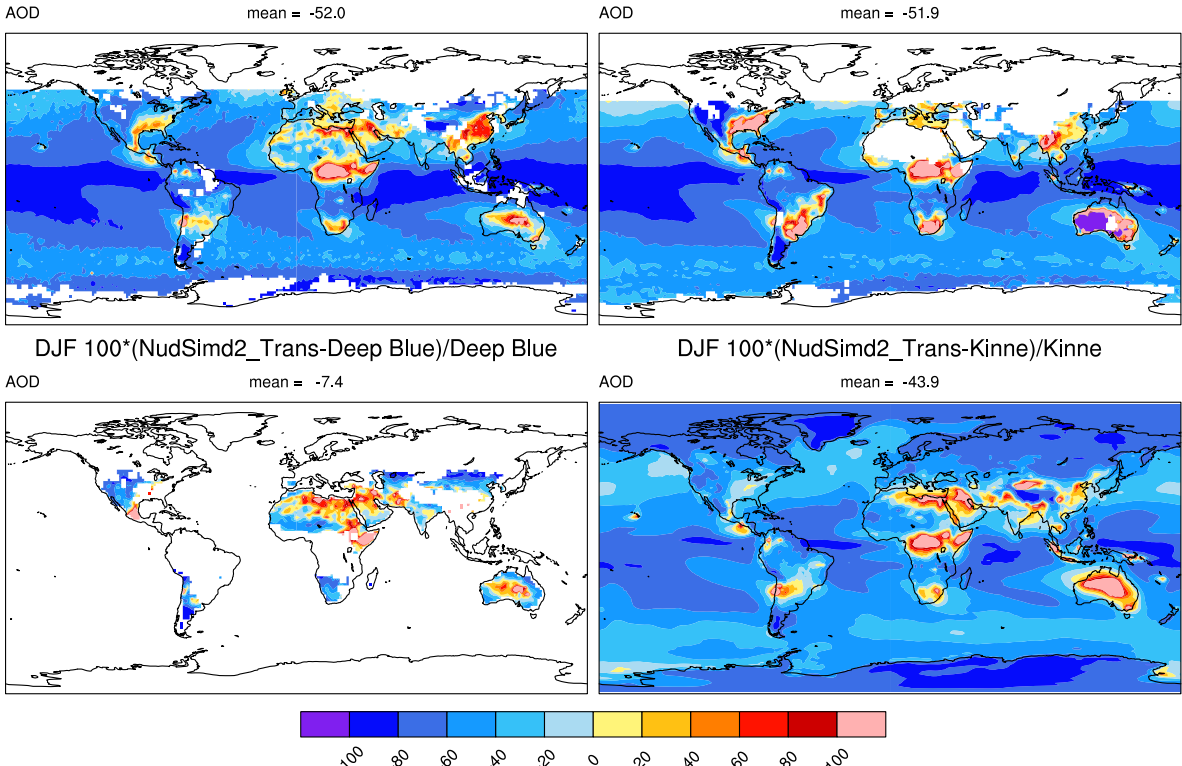

DJF 100*(NudSimd2_Trans-Kinne)/Kinne
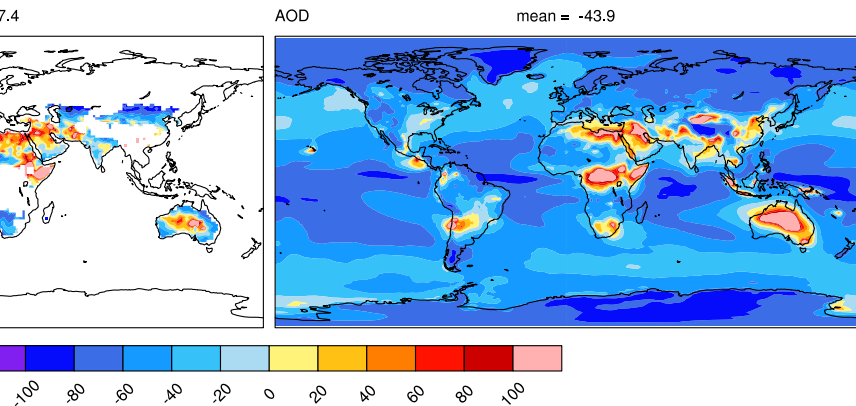

Figure 8. DJF total AOD mean relative differences (2003-2012): 100(NudSimd2_Trans $-x$ ) $/ x$, with $x=$ MISR first row/column, $x=$ Modis Aqua, $x=$ MODIS Deep Blue, and $x=$ Kinne et al. (2013) in the direction of reading. 


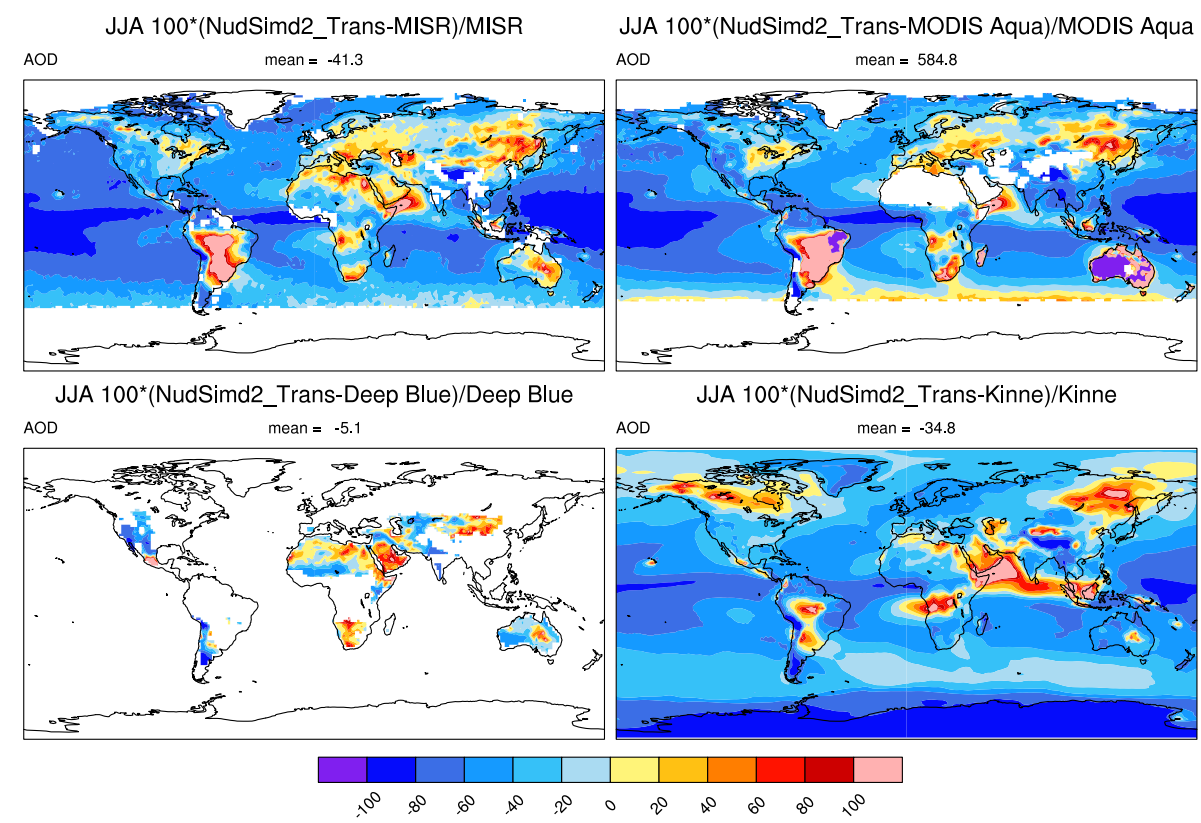

Figure 9. Same as Fig. 8, for JJA.
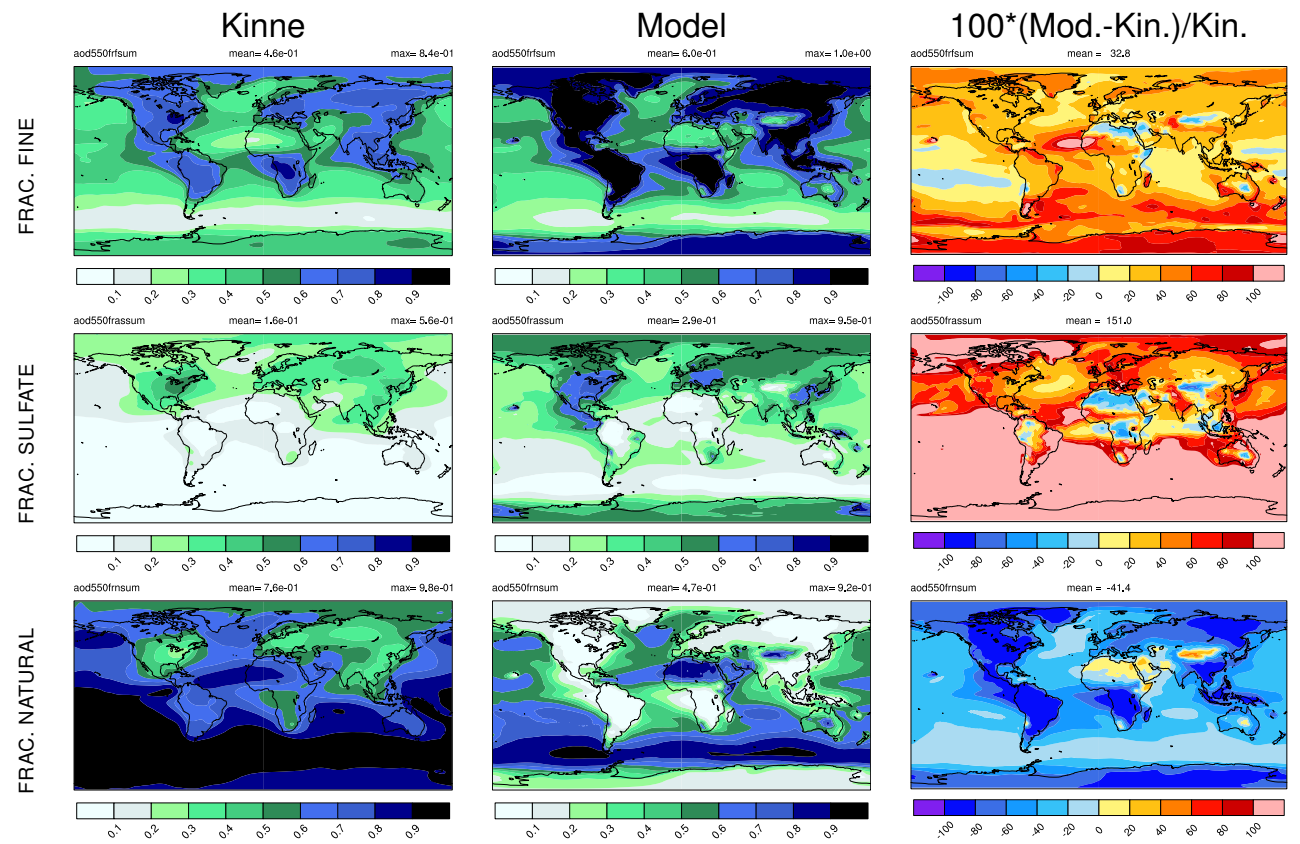

Figure 10. Mean annual fractional AOD from the Kinne et al. (2013) climatology (first column), NudSimd2_Trans simulation (1996-2005) (second column) and relative difference between the two data sets: fractions of fine-mode (first row), of sulfate (second row), and of natural aerosols (third row) (see text for details).

on the modelling of sulfate. Correlation between model outputs and observations is better for the European sites (red dots) than for the US sites (black dots), noting that in all cases it is lower than 0.4. While for sulfate the means of observations and model outputs are very close $(\sim 0.7)$, for $\mathrm{SO}_{2}$ the mean model value is twice that of the mean observed value, some of this overestimation being related to our sulfate precursor including $\mathrm{H}_{2} \mathrm{~S}$ and DMS in addition to $\mathrm{SO}_{2}$.

To go further in the evaluation of the various fractions of the total AOD, Fig. 13 presents, for the selection of twelve AERONET stations as in Cesnulyte et al. (2014), 

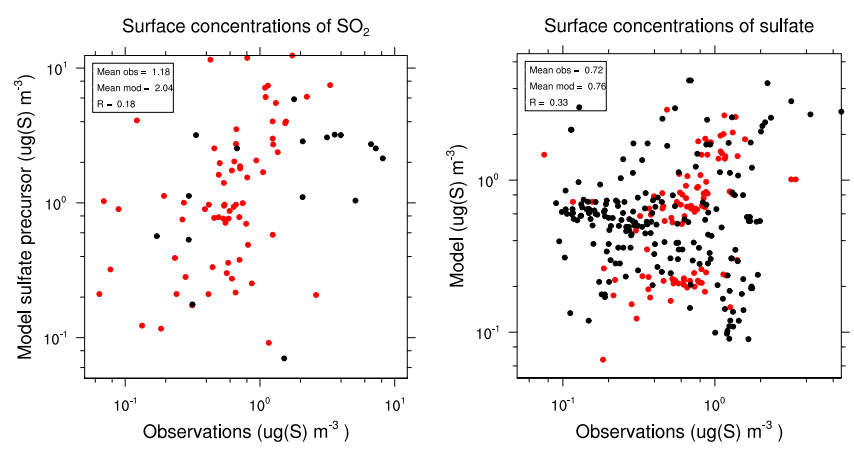

Figure 11. Scatter plot of observations (EBAS database, see text) and corresponding NudSimd2_Trans output: mean annual surface concentrations (2005) of (left) observed $\mathrm{SO}_{2}\left(\mu \mathrm{g}(\mathrm{S}) \mathrm{m}^{-3}\right)$ and modelled sulfate precursor, and (right) sulfate $\left(\mu \mathrm{g}(\mathrm{S}) \mathrm{m}^{-3}\right)$. Red dots are mostly for European sites, while black dots are for US sites. Means of all observations, all model output and correlation coefficients $(R)$ are shown.

the monthly climatological AOD at $550 \mathrm{~nm}$, computed over all years of data available at each given AERONET station. The NudSimd2_Trans binned AODs, at the locations of the AERONET sites, appear in the same figure grouped into SS, $\mathrm{DD}, \mathrm{OM}, \mathrm{BC}$ and $\mathrm{SO}_{4} \mathrm{AODs}$, in addition to the AERONET total AOD, and allow then for an evaluation of the various fractions of the total AOD. These AERONET sites cover various parts of the globe (see Fig. 12 for their locations) and are categorised in three groups depending on the typically dominating aerosol type: urban/anthropogenic for the Ispra, Kanpur, La Jolla, Thessaloniki and Xianghe sites; biomass burning for the Alta Floresta and Mongu sites; and dust for the Cabo Verde, El Arenosillo, Ilorin, La Parguera and Solar Village sites.

The annual cycle of the total AOD is generally well represented by the model, with either a unique narrow peak during the year, such as at the biomass burning site of Alta Floresta in South America, or a peak over several months such as at the dust site of Solar Village in Saudi Arabia, or two peaks as in Kanpur, northern India, which coincide with the preand post-monsoon seasons. The model is also able to capture the range of AODs covered by this selection of areas, going from total AODs lower than 0.2 all year round at La Jolla or El Arenosillo, to medium AODs (around 0.5 in Cabo Verde), and to large AODs around 1 (Alta Floresta). Another characteristic of the model is that, in almost all cases, it shows a low bias.

The low bias is particularly important for the Ispra site (mean yearly bias - MB - of 0.11 ) with sulfate as the dominant aerosol all year round in observations (Cesnulyte et al., 2014), as it is also the case in the model output. This underestimation could be questioned as the data quality score of Kinne et al. (2013) is moderate only for this ISPRA site, the remaining of the Cesnulyte et al. (2014) sites having an excellent quality score. Furthermore, the two nearby sites at the

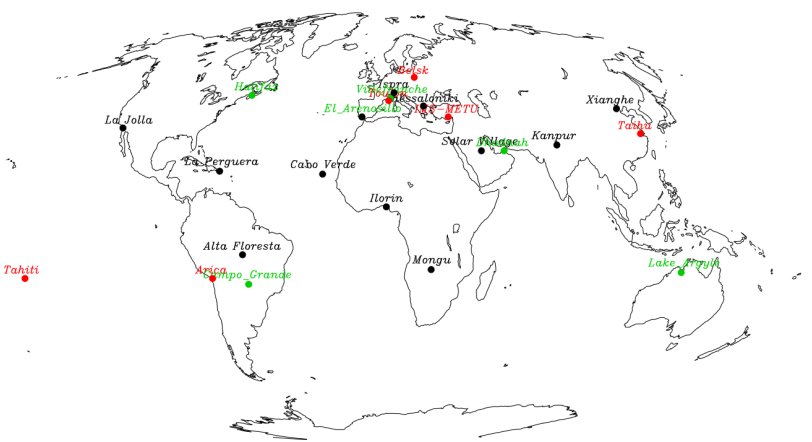

Figure 12. Location of the AERONET stations presented in Fig. 13 with names in black and in Fig. 15 with names in red for poor performance and in green for good performance.

regional scale, Thessaloniki and El Arenosillo, show much better agreement between the model and the observed climatologies, noting however that the dust and sulfate contributions differ for all three sites; for instance, El Arenosillo can be affected by dust storms from northern Africa.

The two Asian sites of Kanpur and Xianghe are also affected by high pollution, and large observed AODs (larger than 0.4) prevailing all year round are underestimated in our simulation by a factor of $\sim 1.8$. The underestimation is even larger at Ilorin $(\mathrm{MB}=0.38)$, located in sub-Saharan Africa, particularly in the dry season months from November to April. This site is obviously under the influence of dust storms; however, Cesnulyte et al. (2014) indicate that fine aerosol from biomass burning make a significant contribution during this dry season, which is a contribution that we seem to be underestimating.

At the two shore/ocean sites of La Jolla (Pacific shore) and of La Parguera (Caribbean Islands), with relatively clean air all year round (total AOD lower than 0.25), the model underestimation appears related to an underestimation of the dust AOD, with dust transported from the nearby Mojave or further away Sahara, respectively (Cesnulyte et al., 2014).

Nevertheless, agreement between model and observations is particularly good at the two biomass sites: Alta Floresta in South America and of Mongu in southern Africa, which is more of a savannah region. This is also the case at the two dust sites: Solar Village in the heart of the Arabian Peninsula, with a small negative MB of -0.07 , and Cabo Verde located $\sim 730 \mathrm{~km}$ of the Senegal coast. The dust transport seems well represented here, although slightly underestimated $(\mathrm{MB}=0.09)$.

As an overall performance of the NudSimd2_Trans simulation, we present in Fig. 14 a Taylor diagram (Taylor, 2001) computed from the time series of the 166 AERONET stations we retained in our analysis (see Sect. 3.2.2) and from the corresponding simulation output at the station location. These time series could in principle cover the 1993-2013 period, but the time period covered is shorter in most cases. Stations have been qualified, according to the dominant aerosol type, 

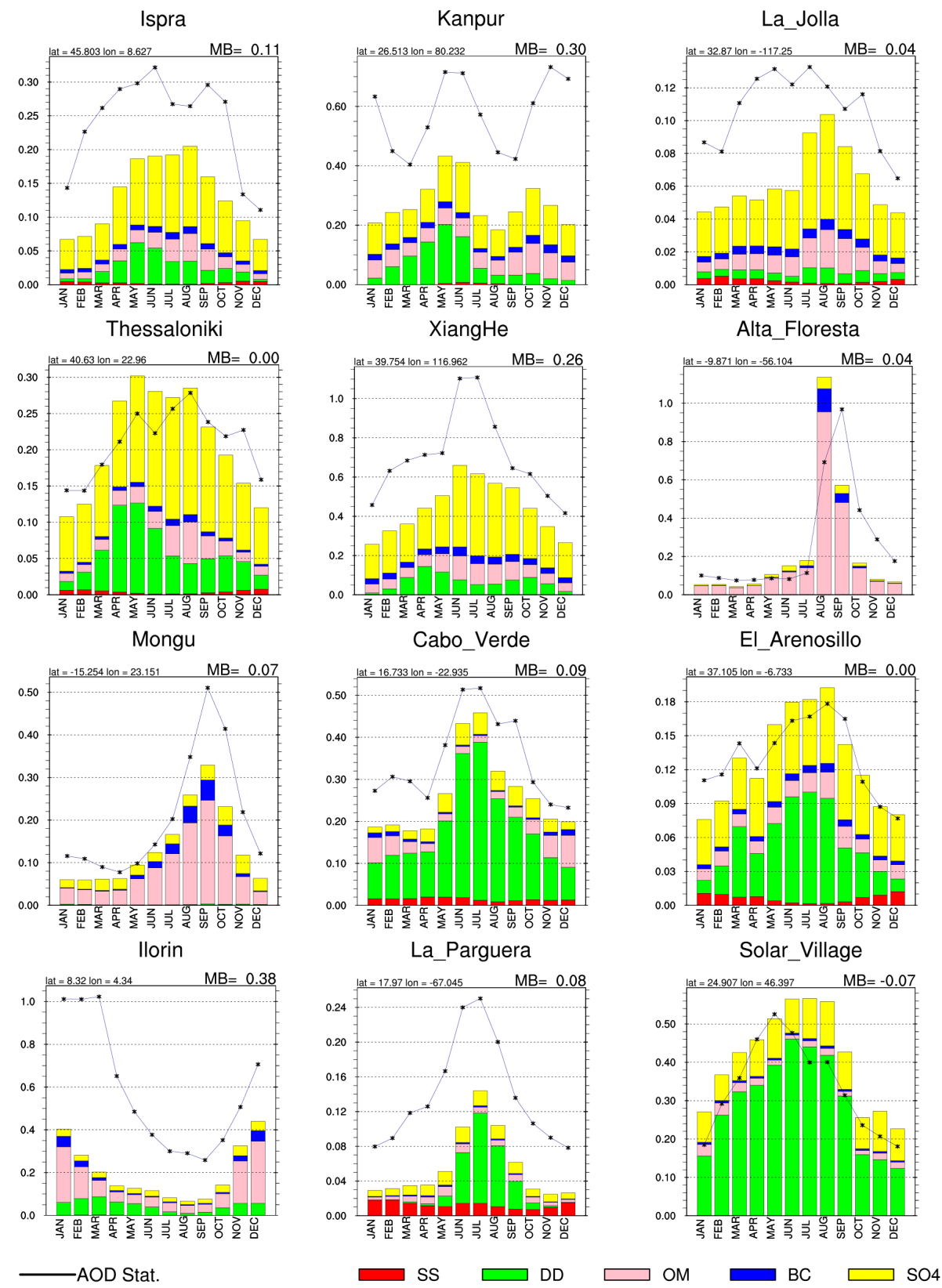

Figure 13. Monthly climatology of AOD, computed from all years of available data, for the AERONET stations of Cesnulyte et al. (2014). Total observed $\mathrm{AOD}$, and $\mathrm{SO}_{4}, \mathrm{BC}, \mathrm{OM}, \mathrm{DD}$ and $\mathrm{SS}$ AODs from the NudSimd2 simulation are displayed.

as ocean, mountain, polar, biomass, coastal, dust, polluted, and land; see Kinne et al. (2013). The most common locations are land (46 stations), coastal (26), and polluted (25). For graphical purposes, negative correlation coefficients have been set to 0 , and normalised standard deviations higher than 1.75 have been set to 1.75 . Overall, the model performs rather satisfactorily with regards to the time correlation between observed and modelled values: the majority of series has correlation coefficients higher than 0.5 (118 stations), this coefficient being higher than 0.7 for 64 stations. With regards to the variability of the series, the diagram reports on the ratio between model and observed standard deviations, and indicates that this ratio is below 0.5 for 29 stations, while it lies between 0.5 and 1.5 for 122 stations.

To further illustrate the behaviour of the model at the monthly timescale, Fig. 15 shows monthly times series, with the same representation of the AOD as in Fig. 13, over all years of data available at a given AERONET site. Included is a selection of six stations performing particularly poorly $(\mathrm{CC}<0.5$ or $\mathrm{rVAR}<0.5$ or $1.5<\mathrm{rVAR})$, followed by a selection of stations performing well $(\mathrm{CC}>0.7$ and $0.5<\mathrm{rVAR}<1.5$ ). According to Kinne et al. (2013), all of 


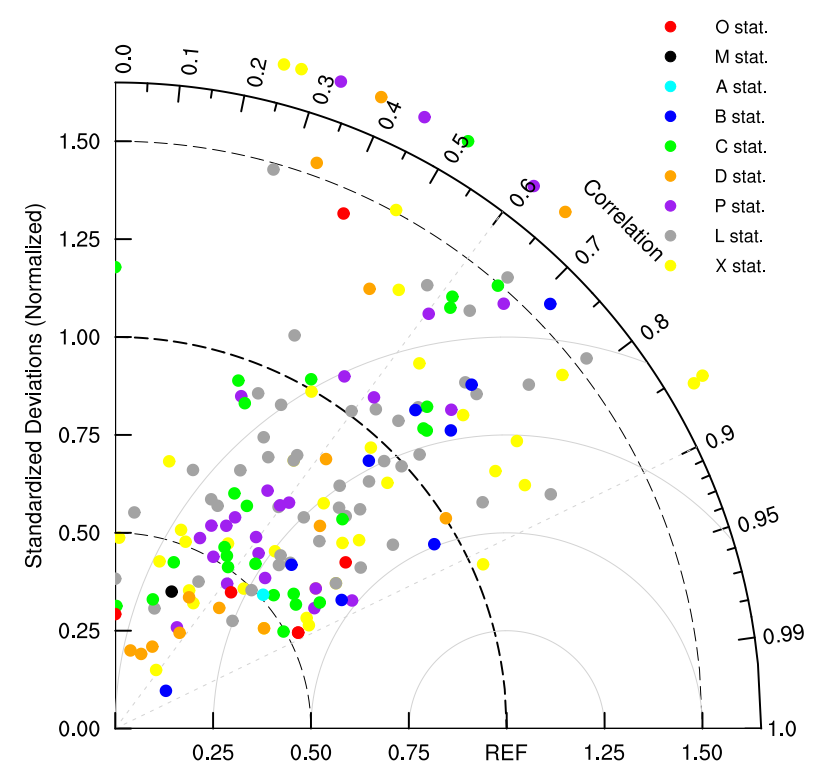

Figure 14. Taylor diagram (Taylor, 2001) for the AOD monthly time series of 166 AERONET stations and outputs from the NudSimd2_Trans simulation (see text for details). The qualification of the stations is that of Kinne et al. (2013) indicating the site's dominant aerosol category (O, ocean; M, mountain; A, polar; B, biomass; C, coastal; D, dust; P, polluted, L, land), and X, no qualification.

these stations have a data quality score of 3 (excellent), and a representativeness score varying between 900 and $100 \mathrm{~km}$. This selection addresses several dominant aerosol types and locations in the world (see Fig. 12).

The Tahiti graph illustrates here again the poor performance of the model over oceans: as in the La Parguera case (see above in this section), the model is all the time too low and misses higher levels of AOD. The Dhadnah and Grande SONDA cases (qualified as performing well) confirm the good climatologies seen for the relatively nearby stations of Solar Village and Alta Floresta by Cesnulyte et al. (2014). In these regions the model appears to perform well over large areas. Similarly, the behaviour of the model is coherent at the Taihu station in China and at the corresponding station of Xianghe (Cesnulyte et al., 2014), with the same underestimation of the observations.

In contrast, while the three stations of IMS-METUERDEMLI, Toulon, and Belsk perform poorly, either because of a poor CC or a poor rVar, the Villefranche station located in the same region of the world performs well. This underlines the challenge of modelling aerosols in that EuroMediterranean region (Nabat et al., 2013, 2014b). The case of Arica, with a MB of 0.22 and an rVar of 0.30 requires further investigation regarding specific conditions, representativity, and quality of the site, which goes beyond the scope of this paper. Finally, to finish on this comparison, which is particularly difficult for a climate model, the cases of Halifax and Lake Argyle, with very different component distributions to the total AOD but with similarly good results, are encouraging.

\subsubsection{Evaluation of vertical distributions}

Figures 16 and 17 display mean vertical profiles of total extinction coefficients $\left(\mathrm{km}^{-1}\right)$ for DJF and JJA, respectively, averaged for individual years. These years cover the 2006 2011 period for the CALIOP instrument, and are representative of the 2004 year for the FreSimd 2 simulation (previously mentioned in Sect. 4.1.1) and the NudSimd2 simulation. We diagnosed vertical information to compare with the CALIOP data from these two simulations only. Profiles are presented for the 12 regions displayed in Koffi et al. (2012), representative of regions with a dominance of marine aerosols (NAT, CAT and NWP regions), of industrial aerosols (EUS, WEU, IND and ECN regions), of dust aerosols (NAF and WCN regions), and of biomass burning aerosols (SAM, CAF, and SAF regions). In addition to these figures, Fig. 18 shows vertical profiles of dust extinction coefficients $\left(\mathrm{km}^{-1}\right)$, for the same simulations/observations as Figs. 16 and 17, for DJF and JJA, and for the six Koffi et al. (2012) regions with a significant contribution of dust aerosols.

In general, the model is biased low compared to the CALIOP data, except for the northern Africa region (NAF), which presents an insignificant bias in DJF and a positive bias between 0.03 and $0.09 \mathrm{~km}^{-1}$ depending on the altitude. The model's low bias is particularly marked for the CAT, WCN (western China), SAF and IND regions. For CAT, the marine boundary layer aerosol load is clearly underestimated in both seasons. This is also the case for the marine NWP region in DJF, but this marine aerosol extinction is correctly simulated in the North Atlantic (NAT) region. For the dust area of Mongolia (WCN), Koffi et al. (2012) indicate that significant CALIOP versus MODIS AOD discrepancies are obtained, e.g., for the WCN dust region DJF bias $=+128 \%$ and SON bias $=+74 \%$. Particularly high interannual variability observed for this WCN region could be due both to its reduced size and to the high variability of the processes responsible for the uplift of the dust particles. Koffi et al. (2012) report a particularly large intermodel (12 model analysed) range for this region of WCN in DJF, probably linked to unresolved processes such as wind gusts, which are not taken into account in our dust emission schemes. The Southern Hemisphere biomass burning SAF low-extinction profiles seem clearly related to the meteorology, including vertical transport and loss by precipitation, as the nudged and free running profiles differ quite a lot. Such a difference appears in JJA over most domains we show. Finally, with regards to profile shapes, the model depicts rather well the convex character of the SAF profiles in JJA, although we do not represent in our model the formation of secondary aerosols from the biomass burning gaseous products during plume aging that contributes to aerosol at high altitudes (Koffi et al., 2012). 

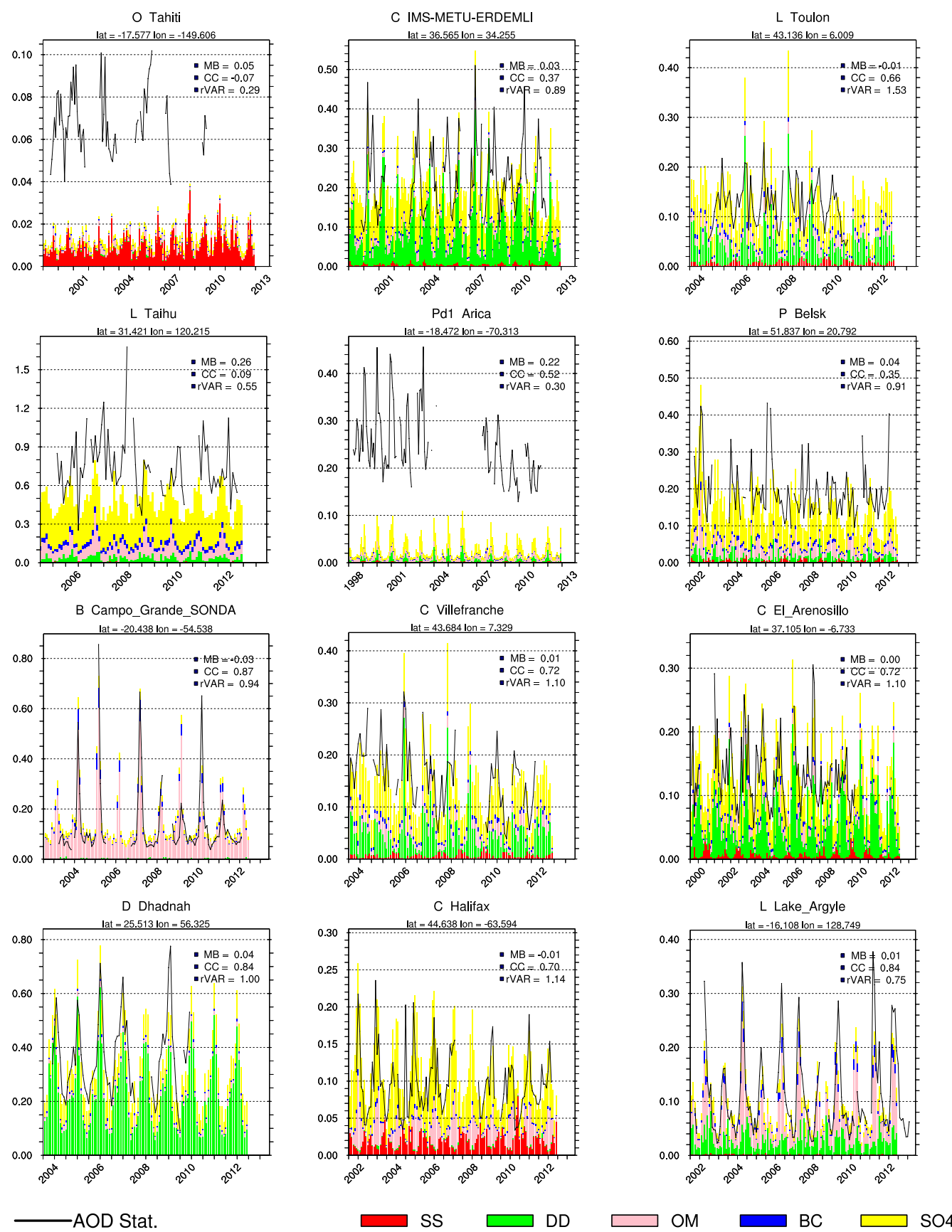

Figure 15. Times series of monthly AODs for a selection of poorly performing AERONET stations, first six images, and of well-performing AERONET stations, last six images, according to the Taylor diagram of Fig. 14. The same AODs as in Fig. 13 are shown. rVAR: ratio of observed versus modelled standard deviations, CC: correlation coefficient between observed and modelled time series, and MB: mean bias.

The seasonality in the vertical profiles of NAF and CAT appears clearly in the model and in the observations, with dust at higher levels due to transport from easterly winds reaching up to $6 \mathrm{~km}$, and advection of the Saharan dust to the Atlantic between 2 and $5 \mathrm{~km}$ (see Fig. 17). Lastly, for the Indian industrial region (IND) the NudSimd2 simulation generates an $\mathrm{S}$ curve shape in JJA that appears quite unique and could be related to an overly large wet deposition sink.
Figure 18, which depicts dust only extinction profiles, provides further insight into the model behaviour: the NAF profiles in Fig. 18, when compared to the profiles of Figs. 16 and 17, confirm that dust is the predominant aerosol in that entire region. This also appears to be the case, although to a lesser extent, in the boundary layer for the $\mathrm{WCN}$ region in DJF, but is not at all the case for the other regions and/or seasons. Agreement between model and observations is good 

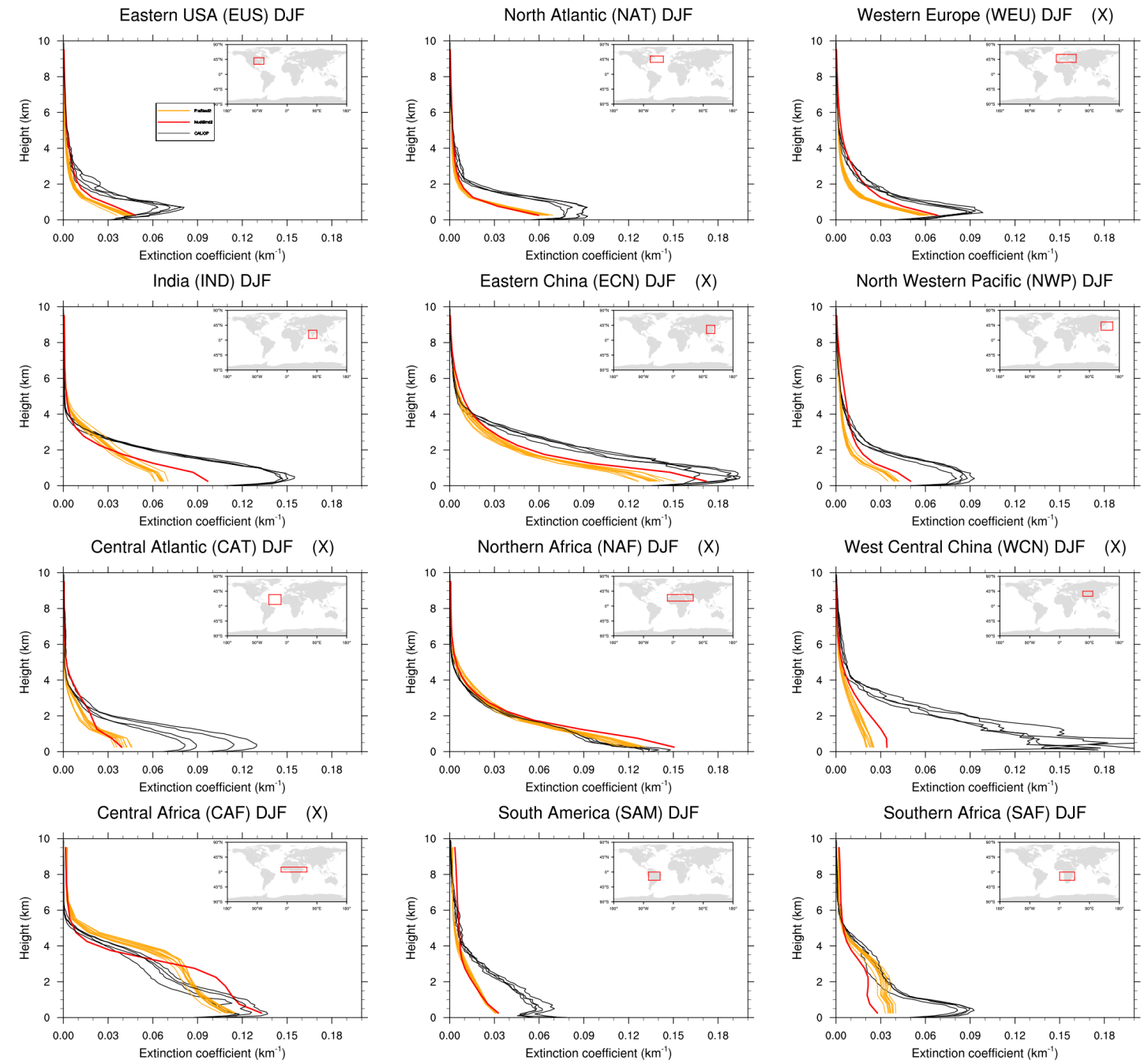

Figure 16. Mean DJF vertical profiles of extinction coefficients $\left(\mathrm{km}^{-1}\right)$ for total aerosols for the FreSimd2 simulation (orange lines) for 2004 (repeated 10 times), the NudSimd2 simulation (red line), and for individual years of the CALIOP 3-D product (black lines), over 12 regions of the globe, as in Koffi et al. (2012) (see in top right corners of individual figures). (X) indicates regions also presented in Fig. 18.

for NWP (north-western Pacific), with very low extinction coefficients and, for instance, for CAF in DJF or for CAT in the $2-4 \mathrm{~km}$ layer in JJA. Agreement is poor for other regions/layer depths such as the DJF CAT 0-2 km range.

\section{Conclusions}

We have introduced a prognostic aerosol scheme (v1) within the atmospheric component ARPEGE-Climat of the CNRMCM6 climate model (Voldoire et al., 2012). Until now, aerosols were prescribed to the model as monthly AODs.

This scheme is based on the GEMS/MACC aerosol module included in the ARPEGE/IFS ECMWF operational forecast model since 2005 (Morcrette et al., 2009), which describes the physical evolution of the five main types of aerosols: BC, OM, DD, SS and sulfate. A total of 12 trac- ers are distinguished in the parameterisations of the physical evolution of the aerosols, which include dry and wet deposition, sedimentation, hygroscopic growth, conversion for sulfate precursors into sulfate, and dynamical emissions of dust and sea salt. Large-scale (advection) and sub-grid-scale (i.e., diffusion and convection) transport of these additional prognostic fields of the atmospheric model are also considered.

We implemented a number of changes in the original scheme such as modifications of the constants involved in the various parameterisations and addition of a new dust emission scheme based on Marticorena and Bergametti (1995) and Kok (2011). Furthermore, biomass burning emissions of $\mathrm{OM}$ and $\mathrm{BC}$ and emissions of SOA have been rescaled (Kaiser et al., 2012; Tsigaridis et al., 2014), as is common practice in aerosol modelling, by a factor of 2 . These changes were aimed at enhancing preliminary low concentrations from our simulations. 

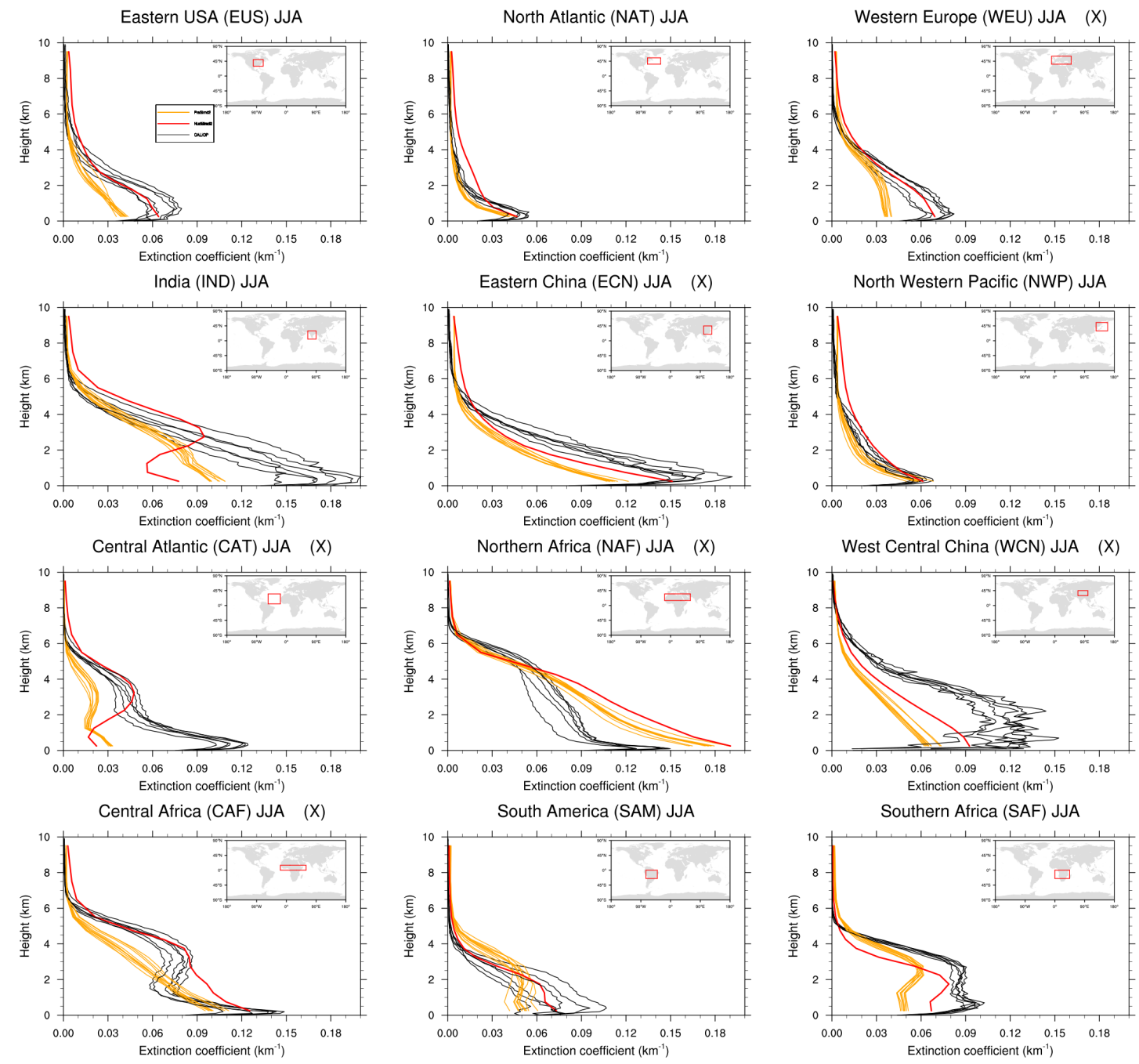

Figure 17. Same as Fig. 16, for the JJA season.

We performed a number of simulations to evaluate different aspects of our modelling of aerosols such as the internal variability of the climate model, the behaviour of freerunning simulations versus nudged simulations, and the sensitivity to the dust emission scheme. Then, transient (19932012) simulations were aimed at validating the model, in a climatological way, from the seasonal to the monthly timescales, against satellite observations, available over the entire or part of the 2003-2012 period, against in situ AERONET measurements available, depending on the site, from 1993, and against the Kinne et al. (2013) global climatology that relies on information from the AERONET stations.

The internal variability of the model has little impact on the seasonal climatology of the AODs of the various aerosols. Differences in AODs between a free-running and a nudged simulation, linked to different meteorologies and to the suppression in free-running simulations of the release of aerosols when re-evaporation of stratiform precipitation occurs, appear lower than 0.05 over most of the globe. Higher differences $(>0.2)$ exist in conjunction with large AODs of biomass-burning-emitted OM in DJF or of dust in JJA. In the end, the performance of a nudged simulation is comparable to that of a free-running simulation.

The analysis of simulations differing by the dust emission scheme alone revealed large differences in both emission fluxes and dust AODs. For the former, global dust emissions are multiplied by 14 using the new scheme, realising that this factor is dependent on the region. This factor varies also according to the dust bin size and, to this end, global mean dust AOD is enhanced by a factor of 4.8 .

The spatial distributions of aerosol concentrations and resulting AODs of, on the one hand, the MACC Reanalysis of reactive gases and aerosols and, on the other hand, our simulations are quite dissimilar, even though the two underlying GCMs share very close aerosol modules. Higher emissions, 

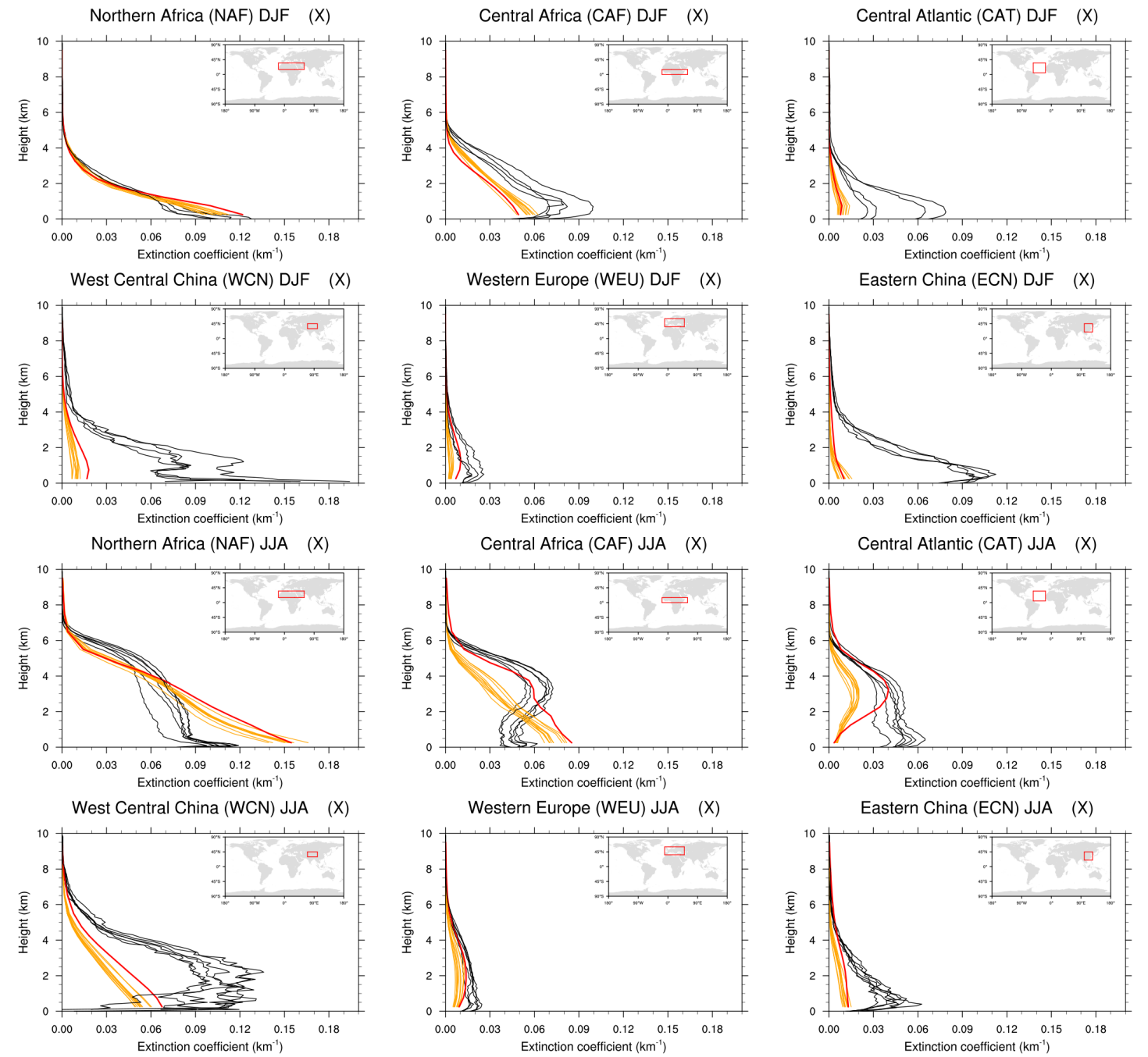

Figure 18. Mean vertical profiles of extinction coefficients $\left(\mathrm{km}^{-1}\right)$ for the dust aerosol, for the FreSimd 2 simulation (orange lines) for 2004 (repeated 10 times), the NudSimd2 simulation (red line), and for individual years of the CALIOP 3-D product (black line), over six regions of the globe with dust aerosols (as in Koffi et al., 2012), for DJF (rows 1 and 2) and JJA (rows 3 and 4).

both dynamic and prescribed, and parameters of the aerosol scheme tuned to reduce aerosol sinks resulted in much lower aerosol concentrations (AODs) away from the source regions in our simulations.

Overall patterns and seasonal cycles of the total AOD are well depicted by our nudged transient simulation when compared to the satellite AOD. Over oceans, however, the model has a systematic low bias of varying importance depending on the observational data set. Over continents, differences are more diverse with patches of low and high biases.

We compared portions of the total simulated AOD with the fractions described in the Kinne et al. (2013) climatology. In general, the model underestimates both the coarse and the natural fractions over continents, except over dustemitting areas. For the natural fraction, this could reflect different aerosol types being considered within the category. In parallel, it appears to overestimate the sulfate fraction over industrialised countries of the Northern Hemisphere.

Evaluation of the various aerosol types has also been performed against AERONET observations of total AOD at $550 \mathrm{~nm}$. Monthly climatologies computed over all years of data available at a given site have been examined at the 12 sites of Cesnulyte et al. (2014). The very diverse annual cycles of the total AOD, with varying dominant aerosol types, are well represented by the model. However, the model shows a systematic low to null bias compared to AERONET observations. This seems to be linked to missing local sources such as biomass burning, or missing more distant sources such as dust transported over the entire Atlantic ocean. Biases are small at true biomass burning or dust sites. 
To go further in qualifying/quantifying the aerosol prognostic scheme, monthly time series of the 166 AERONET sites that add up to 5 years or more of measurements have been compared to model output at the corresponding grid cells. The majority of series have correlation coefficients higher than 0.5 but generally lower variance for the model. Selected time series confirm the difficulty in modelling aerosol at the local scale but outline also the good performance of the model in certain cases.

Finally, an evaluation of the vertical profile has been performed comparing for summer and winter total and dust extinction coefficients from the CALIOP instrument (20062011) and from the model, over the regions analysed in Koffi et al. (2012). The model generally has a low bias, except for the northern Africa region where the bias is high. The distinct shape and seasonality of the profiles are rather well represented by the model. A number of regions where the CALIOP interannual variability is very large (e.g., the WCN region) appear really difficult to simulate.

The evaluation described here indicates that this prognostic aerosol scheme is promising for aerosol-climate studies. We suggest that remaining issues could be addressed by improving aerosol distributions over oceans. This could result from a different sea salt emission scheme or by considering a parameterisation of DMS emissions. Over the continents, there is room for improvement in the modelling of SOA and the inclusion of a simple sulfur cycle, considering prescribed monthly distributions of chemical constituents (e.g., OH, or $\mathrm{O}_{3}$ ), could improve the description of sulfate, which is of primary interest to climate as processes linked to the seasonal or day/night dependence of the chemical reactions that produce sulfate, or linked to the presence/absence of clouds involved in the sulfur aqueous chemistry, would then be considered. Implementing a more realistic description of dry deposition velocities by including the effect of the meteorology through the aerodynamic resistance should also be a step forward. Finally, for longer-term simulations, nitrate, expected to be of growing importance in the future, should also be considered.

\section{Code availability}

A number of model codes developed at CNRM, or in collaboration with CNRM scientists, is available as Open Source code (see https://opensource.cnrm-game-meteo.fr/. However, this is not the case for the aerosol code presented in this paper. This code is nevertheless available upon request from the authors of the paper.

Acknowledgements. This work was supported by Météo-France, CNRS and CERFACS. We particularly acknowledge the support of the team in charge of the CNRM-GAME/CERFACS climate model. We are also grateful to J.-J. Morcrette for many very helpful discussions and advice over several years. Supercomputing time was provided by the Météo-France/DSI supercomputing center. MODIS used in this paper were retrieved from the Giovanni online data system, developed and maintained by the NASA GES DISC. MISR data were obtained from the NASA Langley Research Center Atmospheric Science Data Center, AERONET data from the http://aeronet.gsfc.nasa.gov website, and EBAS data from the http://ebas.nilu.no/ website. We would like to thank B. Koffi, J. Griesfeller and M. Schulz for providing access to CALIOP data from the AeroCom server. We also thank S. Kinne and A. Heil for advice on the Kinne et al. (2013) climatology and on the A2-ACCMIP emissions inventory, respectively. GEMS was funded by the European Commission between 2004 and 2009 as part of the 6th Framework Programme under contract number SIP4-CT-2004-516099, MACC was funded between 2009 and 2011 as part of the 7th Framework Programme, pilot core GMES Atmospheric Service under contract number 218793, and MACC-II since 2011 as part of the 7th Framework Programm under grant agreement no. 283576. ECMWF ERA-Interim data and MACC Reanalysis data used in this study have been provided by ECMWF. We thank E. Paul for his help on the emission and AERONET data processing and displaying of results, and J. Guth for his processing of the EBAS data. Figures were done using the NCL graphic packages, and some of them with the CCMVal Diagnostic Tool. Finally, we are grateful to L. Watson for her kind advice on the nuances of the English language.

Edited by: A. Colette

\section{References}

Andres, R. J. and Kasgnoc, A. D.: A time-averaged inventory of subaerial volcanic sulfur emissions, J. Geophys. Res., 103, 25251-25261, doi:10.1029/98JD02091, 1998.

Bellouin, N., Quaas, J., Morcrette, J.-J., and Boucher, O.: Estimates of aerosol radiative forcing from the MACC re-analysis, Atmos. Chem. Phys., 13, 2045-2062, doi:10.5194/acp-13-20452013, 2013.

Benedetti, A., Morcrette, J.-J., Boucher, O., Dethof, A., Engelen, R. J., Fisher, M., Flentje, H., Huneeus, N., Jones, L., Kaiser, J. W., Kinne, S., Mangold, A., Razinger, M., Simmons, A. J., and Suttie, M.: Aerosol analysis and forecast in the European Centre for Medium-Range Weather Forecasts Integrated Forecast System: 2. Data assimilation, J. Geophys. Res., 114, D13205, doi:10.1029/2008JD011115, 2009.

Benkovitz, C. M., Scholz, M. T., Pacyna, J., Tarrason, L., Dignon, J., Voldner, E. C., Spiro, P. A., Logan, J. A., and Graedel, T. E.: Global gridded inventories of anthropogenic emissions of sulfur and nitrogen, J. Geophys. Res., 101, 29239-29253, 1996.

Boucher, O., Pham, M., and Venkataraman, C.: Simulation of the atmospheric sulfur cycle in the LMD GCM: model description, model evaluation, and global and European budgets, Note 23, 26 pp., Inst. Pierre-Simon Laplace, Paris, France, available at: http://icmc.ipsl.fr/index.php/scientific-notes, 2002.

Boucher, O., Randall, D., Artaxo, P., Bretherton, C., Feingold, G., Forster, P., Kerminen, V.-M., Kondo, Y., Liao, H., Lohmann, U., Rasch, P., Satheesh, S. K., Sherwood, S., Stevens, B., and Zhang, X. Y.: Clouds and aerosols, in: Climate Change 2013: The Physical Science Basis. Contribution of Working Group I to the Fifth Assessment Report of the Intergovernmental Panel on Climate Change, edited by: Stocker, T. F., Qin, D., Plattner, G.- 
K., Tignor, M., Allen, S. K., Boschung, J., Nauels, A., Xia, Y., Bex, V., and Midgley, P. M., Cambridge University Press, Cambridge, UK and New York, NY, USA, 2013.

Bréon, F.-M., Vermeulen, A., and Descloitres, J.: An evaluation of satellite aerosol products against sunphotometers measurements, Remote Sens. Environ., 115, 3102-3111, doi:10.1016/j.rse.2011.06.017, 2011.

Cesnulyte, V., Lindfors, A. V., Pitkänen, M. R. A., Lehtinen, K. E. J., Morcrette, J.-J., and Arola, A.: Comparing ECMWF AOD with AERONET observations at visible and UV wavelengths, Atmos. Chem. Phys., 14, 593-608, doi:10.5194/acp-14593-2014, 2014.

Chin, M., Diehl, T., Tan, Q., Prospero, J. M., Kahn, R. A., Remer, L. A., Yu, H., Sayer, A. M., Bian, H., Geogdzhayev, I. V., Holben, B. N., Howell, S. G., Huebert, B. J., Hsu, N. C., Kim, D., Kucsera, T. L., Levy, R. C., Mishchenko, M. I., Pan, X., Quinn, P. K., Schuster, G. L., Streets, D. G., Strode, S. A., Torres, O., and Zhao, X.-P.: Multi-decadal aerosol variations from 1980 to 2009: a perspective from observations and a global model, Atmos. Chem. Phys., 14, 3657-3690, doi:10.5194/acp14-3657-2014, 2014.

Cuxart, J., Bougeault, P., and Redelsperger, J.-L.: A turbulence scheme allowing for mesoscale and large eddy simulations, Q. J. Roy. Meteor. Soc., 126, 1-30, doi:10.1002/qj.49712656202, 2000.

Dee, D. P., Uppala, S. M., Simmons, A. J., et al.: The ERAInterim reanalysis: configuration and performance of the data assimilation system, Q. J. Roy. Meteor. Soc., 137, 553-597, doi:10.1002/qj.828, 2011.

de Leeuw G., Andreas, E. L., Anguelova, M. D., Fairall, C. W., Lewis, E. R., O’Dowd, C., Schulz, M., and Schwartz, S. E.: Production flux of sea spray aerosol, Rev. Geophys., 49, RG2001, doi:10.1029/2010RG000349, 2011.

Dentener, F., Kinne, S., Bond, T., Boucher, O., Cofala, J., Generoso, S., Ginoux, P., Gong, S., Hoelzemann, J. J., Ito, A., Marelli, L., Penner, J. E., Putaud, J.-P., Textor, C., Schulz, M., van der Werf, G. R., and Wilson, J.: Emissions of primary aerosol and precursor gases in the years 2000 and 1750 prescribed data-sets for AeroCom, Atmos. Chem. Phys., 6, 4321-4344, doi:10.5194/acp-64321-2006, 2006.

Diehl, T., Heil, A., Chin, M., Pan, X., Streets, D., Schultz, M., and Kinne, S.: Anthropogenic, biomass burning, and volcanic emissions of black carbon, organic carbon, and $\mathrm{SO}_{2}$ from 1980 to 2010 for hindcast model experiments, Atmos. Chem. Phys. Discuss., 12, 24895-24954, doi:10.5194/acpd-12-24895-2012, 2012.

Douville, H.: Stratospheric polar vortex influence on Northern Hemisphere winter climate variability, Geophys. Res. Lett., 36, L18703, doi:10.1029/2009GL039334, 2009.

Ekman, A. M. L.: Do sophisticated parameterizations of aerosolcloud interactions in CMIP5 models improve the representation of recent observed temperature trends?, J. Geophys. Res.Atmos., 119, 817-832, doi:10.1002/2013JD020511, 2014.

Evan, A. T., Flamant, C., Fiedler, S., and Doherty, O., An analysis of aeolian dust in climate models, Geophys. Res. Lett., 41, 59966001, doi:10.1002/2014GL060545, 2014.

Fairall, C. W., Bradley, E. F., Hare, J. E., Grachev, A. A., and Edson, J. B.: Bulk parameterization of air-sea fluxes: updates and verification for the COARE algorithm, J. Climate, 16, 571-591, 2003.

Flato, G., Marotzke, J., Abiodun, B., Braconnot, P., Chou, S. C., Collins, W., Cox, P., Driouech, F., Emori, S., Eyring, V., Forest, C., Gleckler, P., Guilyardi, E., Jakob, C., Kattsov, V., Reason, C., and Rummukainen, M.: Evaluation of Climate Models, in: Climate Change 2013: The Physical Science Basis. Contribution of Working Group I to the Fifth Assessment Report of the Intergovernmental Panel on Climate Change, edited by: Stocker, T. F., Qin, D., Plattner, G.-K., Tignor, M., Allen, S. K., Boschung, J., Nauels, A., Xia, Y., Bex, V., and Midgley, P. M., Cambridge University Press, Cambridge, United Kingdom and New York, NY, USA, 2013.

Ginoux, P., Chin, M., Tegen, I., Prospero, J., Holben, B. N., Dubovik, O., and Lin, S.-J.: Sources and distributions of dust aerosols simulated with the GOCART model, J. Geophys. Res., 106, 20255-20274, 2001.

Guérémy, J. F.: A continuous buoyancy based convection scheme: one- and three-dimensional validation, Tellus A, 63, 687-706, doi:10.1111/j.1600-0870.2011.00521.x, 2011.

Granier, C., Bessagnet, B., Bond, T., D’Angiola, A., Denier Van Der Gon, H., Frost, G. J., Heil, A., Kaiser, J. W., Kinne, S., Klimont, Z. S. Kloster, Lamarque, J.-F., Liousse, C., Masui, T., Meleux, F., Mieville, A., Ohara, T., Raut, J.-C., Riahi, K., Schultz, M. G., Smith, S. J., Thompson, A., van Aardenne, J., van der Werf, G. R., and van Vuuren, D. P.: Evolution of anthropogenic and biomass burning emissions of air pollutants at global and regional scales during the 1980-2010 period, Climatic Change, 109, 163-190, 2011.

Grythe, H., Ström, J., Krejci, R., Quinn, P., and Stohl, A.: A review of sea-spray aerosol source functions using a large global set of sea salt aerosol concentration measurements, Atmos. Chem. Phys., 14, 1277-1297, doi:10.5194/acp-14-1277-2014, 2014.

Guelle, W., Schulz, M., Balkanski, Y., and Dentener, F.: Influence of the source formulation on modeling the atmospheric global distribution of the sea salt aerosol, J. Geophys. Res., 106, 27509_ 27524, 2001.

Holben, B. N., Eck, T. F., Slutsker, I., Tanré, D., Buis, J. P., Setzer, A., Vermote, E., Reagan, J. A., Kaufman, Y., Nakajima, T., Lavenu, F., Jankowiak, I., and Smirnov, A.: AERONETA Federated Instrument Network and Data Archive for Aerosol Char1205 acterization, Remote Sens. Environ., 66, 1-16, doi:10.1016/S0034-4257(98)00031-5, 1998.

Holben, B. N., Eck, T. F., Slutsker, I., Smirnov, A., Sinyuk, A., Schafer, J., Giles, D., and Dubovik, O.: AERONET's version 2.0 quality assurance criteria, in: Remote Sensing of the Atmosphere and Clouds, Proc. SPIE, 6408, 64080Q, doi:10.1117/12.706524, 2006.

Hollingsworth, A., Engelen, R. J., Benedetti, A., Dethof, A., Flemming, J., Kaiser, J. W., Morcrette, J.-J., Simmons, A. J., Textor, C., Boucher, O., Chevallier, F., Rayner, P., Elbern, H., Eskes, H., Granier, C., Peuch, Rouil, L., and Schultz, M. G.: The Global Earth-system Monitoring using Satellite and in-situ data (GEMS) project: Towards a monitoring and forecasting system for atmospheric composition, B. Am. Meteorol. Soc., 89, 11471164, doi:10.1175/2008BAMS2355.1, 2008.

Houghton, J. T., Ding, Y., Griggs, D. J., Noguer, M., van der Linden, P. J., and Xiaosu, D.: Climate Change: The Scientific Basis, contribution of Working Group I to the Third Assessment Re- 
port of the Intergovernmental Panel on Climate Change (IPCC), Cambridge University Press, UK, 2001.

Huneeus, N.: Assimilation variationnelle d'observations satellitaires dans un modèle atmosphérique d'aérosols, thèse Université Lille 1 - Sciences et technologies, 2007.

Huneeus, N., Boucher, O., and Chevallier, F.: Simplified aerosol modeling for variational data assimilation, Geosci. Model Dev., 2, 213-229, doi:10.5194/gmd-2-213-2009, 2009.

Huneeus, N., Schulz, M., Balkanski, Y., Griesfeller, J., Prospero, J., Kinne, S., Bauer, S., Boucher, O., Chin, M., Dentener, F., Diehl, T., Easter, R., Fillmore, D., Ghan, S., Ginoux, P., Grini, A., Horowitz, L., Koch, D., Krol, M. C., Landing, W., Liu, X., Mahowald, N., Miller, R., Morcrette, J.-J., Myhre, G., Penner, J., Perlwitz, J., Stier, P., Takemura, T., and Zender, C. S.: Global dust model intercomparison in AeroCom phase I, Atmos. Chem. Phys., 11, 7781-7816, doi:10.5194/acp-11-7781-2011, 2011.

Huneeus, N., Chevallier, F., and Boucher, O.: Estimating aerosol emissions by assimilating observed aerosol optical depth in a global aerosol model, Atmos. Chem. Phys., 12, 4585-4606, doi:10.5194/acp-12-4585-2012, 2012.

Hsu, N. C., Tsay, S.-C., King, M., and Herman, J. R.: Aerosol properties over bright-reflecting source regions, IEEE T. Geosci. Remote, 42, 557-569, doi:10.1109/TGRS.2004.824067, 2004.

Inness, A., Baier, F., Benedetti, A., Bouarar, I., Chabrillat, S., Clark, H., Clerbaux, C., Coheur, P., Engelen, R. J., Errera, Q., Flemming, J., George, M., Granier, C., Hadji-Lazaro, J., Huijnen, V., Hurtmans, D., Jones, L., Kaiser, J. W., Kapsomenakis, J., Lefever, K., Leitão, J., Razinger, M., Richter, A., Schultz, M. G., Simmons, A. J., Suttie, M., Stein, O., Thépaut, J.-N., Thouret, V., Vrekoussis, M., Zerefos, C., and the MACC team: The MACC reanalysis: an 8 yr data set of atmospheric composition, Atmos. Chem. Phys., 13, 4073-4109, doi:10.5194/acp-13-4073-2013, 2013.

IPCC: Climate Change 2007: Synthesis Report. Contribution of Working Groups I, II and III to the Fourth Assessment Report of the Intergovernmental Panel on Climate Change, core writing team, edited by: Pachauri, R. K. and Reisinger, A., IPCC, Geneva, Switzerland, 2007.

Kaiser, J. W., Heil, A., Andreae, M. O., Benedetti, A., Chubarova, N., Jones, L., Morcrette, J.-J., Razinger, M., Schultz, M. G., Suttie, M., and van der Werf, G. R.: Biomass burning emissions estimated with a global fire assimilation system based on observed fire radiative power, Biogeosciences, 9, 527-554, doi:10.5194/bg-9-527-2012, 2012.

Kahn, R. A., Gaitley, B. J., Martonchik, J. V., Diner, D. J., Crean, K. A., and Holben, B.: Multiangle imaging spectroradiometer (misr) global aerosol optical depth validation based on 2 years of coincident aerosol robotic network (aeronet) observations, J. Geophys. Res., 110, D10S04, doi:10.1029/2004JD004706, 2005.

Kahn, R. A., Gaitley, B. J., Garay, M. J., Diner, D. J., Eck, T. F., Smirnov, A., and Holben, B. N.: Multiangle Imaging SpectroRadiometer global aerosol product assessment by comparison with the Aerosol Robotic Network, J. Geophys. Res., 115, D23209, doi:10.1029/2010JD014601, 2010.

Kaufman, Y. J., Tanré D., and Boucher, O.: A satellite view of aerosols in the climate system, Nature, 419, 215-223, 2002.

Kettle, A. J., Andreae, M. O., Amouroux, D., Andreae, T. W., Bates, T. S., Berresheim, H., Bingemer, H., Boniforti, R., Curran, M. A. J., DiTullio, G. R., Helas, G., Jones, G. B.,
Keller, M. D.: A global database of sea surface dimethylsulfide (DMS) measurements and a simple model to predict sea surface DMS as a function of latitude, longitude and month, Global Biogeochem. Cy., 13, 399-444, 1999.

Kinne, S., Schulz, M., Textor, C., Guibert, S., Balkanski, Y., Bauer, S. E., Berntsen, T., Berglen, T. F., Boucher, O., Chin, M., Collins, W., Dentener, F., Diehl, T., Easter, R., Feichter, J., Fillmore, D., Ghan, S., Ginoux, P., Gong, S., Grini, A., Hendricks, J., Herzog, M., Horowitz, L., Isaksen, I., Iversen, T., Kirkevåg, A., Kloster, S., Koch, D., Kristjansson, J. E., Krol, M., Lauer, A., Lamarque, J. F., Lesins, G., Liu, X., Lohmann, U., Montanaro, V., Myhre, G., Penner, J., Pitari, G., Reddy, S., Seland, O., Stier, P., Takemura, T., and Tie, X.: An AeroCom initial assessment - optical properties in aerosol component modules of global models, Atmos. Chem. Phys., 6, 1815-1834, doi:10.5194/acp-6-1815-2006, 2006.

Kinne, S., O'Donnel, D., Stier, P., Kloster, S., Zhang, K., Schmidt, H., Rast, S., Giorgetta, M., Eck, T. F., and Stevens, B.: MAC-v1: a new global aerosol climatology for climate studies, J. Adv. Model. Earth Syst., 5, 704-740, doi:10.1002/jame.20035, 2013.

Koffi, B., Schulz, M., Bréon, F.-M., Griesfeller, J., Winker, D., Balkanski, Y., Bauer, S., Berntsen, T., Chin, M., Collins, W. D., Dentener, F., Diehl, T., Easter, R., Ghan, S., Ginoux, P., Gong, S., Horowitz, L. W., Iversen, T., Kirkevåg, A., Koch, D., Krol, M., Myhre, G., Stier, P., and Takemura, T.: Application of the CALIOP layer product to evaluate the vertical distribution of aerosols estimated by global models: AeroCom phase I results, J. Geophys. Res., 117, D10201, doi:10.1029/2011JD016858, 2012.

Kok, J. F.: A scaling theory for the size distribution of emitted dust aerosols suggests climate models underestimate the size of the global dust cycle, Proc. Natl. Acad. Sci. USA, 108, 1016-1021, 2011.

Lamarque, J.-F., Bond, T. C., Eyring, V., Granier, C., Heil, A., Klimont, Z., Lee, D., Liousse, C., Mieville, A., Owen, B., Schultz, M. G., Shindell, D., Smith, S. J., Stehfest, E., Van Aardenne, J., Cooper, O. R., Kainuma, M., Mahowald, N., McConnell, J. R., Naik, V., Riahi, K., and van Vuuren, D. P.: Historical (1850-2000) gridded anthropogenic and biomass burning emissions of reactive gases and aerosols: methodology and application, Atmos. Chem. Phys., 10, 7017-7039, doi:10.5194/acp10-7017-2010, 2010.

Lamarque, J.-F., Shindell, D. T., Josse, B., Young, P. J., Cionni, I., Eyring, V., Bergmann, D., Cameron-Smith, P., Collins, W. J., Doherty, R., Dalsoren, S., Faluvegi, G., Folberth, G., Ghan, S. J., Horowitz, L. W., Lee, Y. H., MacKenzie, I. A., Nagashima, T., Naik, V., Plummer, D., Righi, M., Rumbold, S. T., Schulz, M., Skeie, R. B., Stevenson, D. S., Strode, S., Sudo, K., Szopa, S., Voulgarakis, A., and Zeng, G.: The Atmospheric Chemistry and Climate Model Intercomparison Project (ACCMIP): overview and description of models, simulations and climate diagnostics, Geosci. Model Dev., 6, 179-206, doi:10.5194/gmd-6-179-2013, 2013.

Lee, Y. H., Lamarque, J.-F., Flanner, M. G., Jiao, C., Shindell, D. T., Berntsen, T., Bisiaux, M. M., Cao, J., Collins, W. J., Curran, M., Edwards, R., Faluvegi, G., Ghan, S., Horowitz, L. W., McConnell, J. R., Ming, J., Myhre, G., Nagashima, T., Naik, V., Rumbold, S. T., Skeie, R. B., Sudo, K., Takemura, T., Thevenon, F., Xu, B., and Yoon, J.-H.: Evaluation of prein- 
dustrial to present-day black carbon and its albedo forcing from Atmospheric Chemistry and Climate Model Intercomparison Project (ACCMIP), Atmos. Chem. Phys., 13, 2607-2634, doi:10.5194/acp-13-2607-2013, 2013.

Levy, R. C., Remer, L. A., Mattoo, S., Vermote, E. F., and Kaufman, Y. J.: Second-generation operational algorithm: retrieval of aerosol properties over land from inversion of moderate resolution imaging spectroradiometer spectral reflectance, J. Geophys. Res., 112, D13211, doi:10.1029/2006JD007811, 2007.

Liu, X., Easter, R. C., Ghan, S. J., Zaveri, R., Rasch, P., Shi, X., Lamarque, J.-F., Gettelman, A., Morrison, H., Vitt, F., Conley, A., Park, S., Neale, R., Hannay, C., Ekman, A. M. L., Hess, P., Mahowald, N., Collins, W., Iacono, M. J., Bretherton, C. S., Flanner, M. G., and Mitchell, D.: Toward a minimal representation of aerosols in climate models: description and evaluation in the Community Atmosphere Model CAM5, Geosci. Model Dev., 5, 709-739, doi:10.5194/gmd-5-709-2012, 2012.

Lohmann, U. and Feichter, J.: Global indirect aerosol effects: a review, Atmos. Chem. Phys., 5, 715-737, doi:10.5194/acp-5-7152005, 2005.

Lopez, P.: Implementation and validation of a new prognostic large-scale cloud and precipitation scheme for climate and dataassimilation purposes, Q. J. Roy. Meteor. Soc., 128, 229-257, 2002.

Mallet, M., Dubovik, O., Nabat, P., Dulac, F., Kahn, R., Sciare, J., Paronis, D., and Léon, J. F.: Absorption properties of Mediterranean aerosols obtained from multi-year ground-based remote sensing observations, Atmos. Chem. Phys., 13, 9195-9210, doi:10.5194/acp-13-9195-2013, 2013.

Mangold, A., De Backer, H., De Paepe, B., Dewitte, S., Chiapello, I., Derimian, Y., Kacenelenbogen, M. J., Léon, F., Huneeus, N., Schulz, M., Ceburnis, D., O’Dowd, C., Flentje, H., Kinne, S., Benedetti, A., Morcrette, J.-J., and Boucher, O.: Aerosol analysis and forecast in the European Centre for Medium-Range Weather Forecasts Integrated Forecast System: 3. Evaluation by means of case studies, J. Geophys. Res., 116, D03302, doi:10.1029/2010JD014864, 2011.

Marticorena, B. and Bergametti, G.: Modeling the atmospheric dust cycle: 1 . Design of a soil-derived dust emission scheme, J. Geophys. Res., 100, 16415-16430, doi:10.1029/95JD00690, 1995.

Masson, V., Champeaux, J., Chauvin, F., Meriguet, C., and Lacaze, R.: A global database of land surface parameters at 1-km resolution in meteorological and climate models, J. Climate, 16, 1261-1282, 2003.

Masson, V., Le Moigne, P., Martin, E., Faroux, S., Alias, A., Alkama, R., Belamari, S., Barbu, A., Boone, A., Bouyssel, F., Brousseau, P., Brun, E., Calvet, J.-C., Carrer, D., Decharme, B., Delire, C., Donier, S., Essaouini, K., Gibelin, A.-L., Giordani, H., Habets, F., Jidane, M., Kerdraon, G., Kourzeneva, E., Lafaysse, M., Lafont, S., Lebeaupin Brossier, C., Lemonsu, A., Mahfouf, J.-F., Marguinaud, P., Mokhtari, M., Morin, S., Pigeon, G., Salgado, R., Seity, Y., Taillefer, F., Tanguy, G., Tulet, P., Vincendon, B., Vionnet, V., and Voldoire, A.: The SURFEXv7.2 land and ocean surface platform for coupled or offline simulation of earth surface variables and fluxes, Geosci. Model Dev., 6, 929-960, doi:10.5194/gmd-6-929-2013, 2013.

Melas, D., Katragkou, E., Schulz, M., Lefever, K., Huijnen, V., and Eskes, H.: Validation report of the MACC reanalysis of global atmospheric composition Period 2003-2012, MACC-II Deliverable D_83.5, 2013.

Morcrette, J.-J., Beljaars, A., Benedetti, A., Jones, L., and Boucher, O.: Sea-salt and dust aerosols in the ECMWF IFS model, Geophys. Res. Lett., 35, L24813, doi:10.1029/2008GL036041, 2008.

Morcrette, J.-J., Boucher, O., Jones, L., Salmond, D., Bechtold, P., Beljaars, A., Benedetti, A., Bonet, A., Kaiser, J. W., Razinger, M., Schulz, M., Serrar, S., Simmons, A. J., Sofiev, M., Suttie, M., Tompkins, A. M., and Untch, A.: Aerosol analysis and forecast in the European Centre for Medium-Range Weather Forecasts Integrated Forecast System: forward modeling, J. Geophys. Res., 114, D06206, doi:10.1029/2008JD011235, 2009.

Morcrette, J.-J., Benedetti, A., Jones, L., Kaiser, J. W., Razinger, M., and Suttie, M.: Prognostic aerosols in the ECMWF IFS: MACC vs. GEMS aerosols, ECMWF Tech. Mem. 659, ECMWF, December 2011, 2011a.

Morcrette, J.-J., Benedetti, A., Ghelli, A., Kaiser, J. W., and Tompkins, A. M.: Aerosol-Cloud-Radiation Interactions and their Impact on ECMWF/MACC Forecasts, ECMWF Tech. Mem. 660, ECMWF, December 2011, 2011b.

Myhre, G., Samset, B. H., Schulz, M., Balkanski, Y., Bauer, S., Berntsen, T. K., Bian, H., Bellouin, N., Chin, M., Diehl, T., Easter, R. C., Feichter, J., Ghan, S. J., Hauglustaine, D., Iversen, T., Kinne, S., Kirkevag, A., Lamarque, J.-F., Lin, G., Liu, X., Lund, M. T., Luo, G., Ma, X., van Noije, T., Penner, J. E., Rasch, P. J., Ruiz, A., Seland, O., Skeie, R. B., Stier, P., Takemura, T., Tsigaridis, K., Wang, P., Wang, Z., Xu, L., Yu, H., Yu, F., Yoon, J.-H., Zhang, K., Zhang, H., and Zhou, C.: Radiative forcing of the direct aerosol effect from AeroCom Phase II simulations, Atmos. Chem. Phys., 13, 1853-1877, doi:10.5194/acp-13-18532013, 2013.

Nabat, P., Solmon, F., Mallet, M., Kok, J. F., and Somot, S.: Dust emission size distribution impact on aerosol budget and radiative forcing over the Mediterranean region: a regional climate model approach, Atmos. Chem. Phys., 12, 10545-10567, doi:10.5194/acp-12-10545-2012, 2012.

Nabat, P., Somot, S., Mallet, M., Chiapello, I., Morcrette, J. J., Solmon, F., Szopa, S., Dulac, F., Collins, W., Ghan, S., Horowitz, L. W., Lamarque, J. F., Lee, Y. H., Naik, V., Nagashima, T., Shindell, D., and Skeie, R.: A 4-D climatology (1979-2009) of the monthly tropospheric aerosol optical depth distribution over the Mediterranean region from a comparative evaluation and blending of remote sensing and model products, Atmos. Meas. Tech., 6, 1287-1314, doi:10.5194/amt-6-12872013, 2013.

Nabat, P., Somot, S., Mallet, M., Sanchez-Lorenzo, A., and Wild, M.: Contribution of anthropogenic sulfate aerosols to the changing Euro-Mediterranean climate since 1980, Geophys. Res. Lett., 41, 5605-5611, doi:10.1002/2014GL060798, 2014a.

Nabat, P., Somot, S., Mallet, M., Michou, M., Sevault, F., Driouech, F., Meloni, D., Di Sarra, A., Di Biagio, C., Formenti, P., Sicard, M., Léon, J.-F., and Bouin, M.-N.: Dust aerosol radiative effects during summer 2012 simulated with a coupled regional aerosolatmosphere-ocean model over the Mediterranean, Atmos. Chem. Phys. Discuss., 14, 25351-25410, doi:10.5194/acpd-14-253512014, 2014b.

Pan, X., Chin, M., Gautam, R., Bian, H., Kim, D., Colarco, P. R., Diehl, T. L., Takemura, T., Pozzoli, L., Tsigaridis, K., Bauer, S., 
and Bellouin, N.: A multi-model evaluation of aerosols over South Asia: Common problems and possible causes, Atmos. Chem. Phys. Discuss., 14, 19095-19147, doi:10.5194/acpd-1419095-2014, 2014.

Piriou, J.-M., Redelsperger, J.-L., Geleyn, J.-F., Lafore, J.-P., and Guichard, F.: An approach for convective parameterization with memory, in separating microphysics and transport in grid-scale equations, J. Atmos. Sci., 64, 4127-4139, 2007.

Reddy, M. S., Boucher, O., Bellouin, N., Schulz, M., Balkanski, Y., Dufresne, J.-L., and Pham, M.: Estimates of global multicomponent aerosol optical depth and direct radiative perturbation in the Laboratoire de Météorologie Dynamique general circulation model, J. Geophys. Res., 110, D10S16, doi:10.1029/2004JD004757, 2005.

Riahi, K., Rao, S., Krey, V., Cho, C., Chirkov, V., Fischer, G., Kindermann, G., Nakicenovic, N., and Rafaj, P.: RCP 8.5 a scenario of comparatively high greenhouse gas emissions, Climatic Change, 109, 33-57, doi:10.1007/s10584-011-0149-y, 2011.

Schulz, M., Textor, C., Kinne, S., Balkanski, Y., Bauer, S., Berntsen, T., Berglen, T., Boucher, O., Dentener, F., Guibert, S., Isaksen, I. S. A., Iversen, T., Koch, D., Kirkevag, A., Liu, X., Montanaro, V., Myhre, G., Penner, J. E., Pitari, G., Reddy, S., Seland, O., Stier, P., and Takemura, T.: Radiative forcing by aerosols as derived from the AeroCom present-day and pre-industrial simulations, Atmos. Chem. Phys., 6, 5225-5246, doi:10.5194/acp-65225-2006, 2006.

Sessions, W. R., Reid, J. S., Benedetti, A., Colarco, P. R., da Silva, A., Lu, S., Sekiyama, T., Tanaka, T. Y., Baldasano, J. M., Basart, S., Brooks, M. E., Eck, T. F., Iredell, M., Hansen, J. A., Jorba, O. C., Juang, H.-M. H., Lynch, P., Morcrette, J.-J., Moorthi, S., Mulcahy, J., Pradhan, Y., Razinger, M., Sampson, C. B., Wang, J., and Westphal, D. L.: Development towards a global operational aerosol consensus: basic climatological characteristics of the International Cooperative for Aerosol Prediction MultiModel Ensemble (ICAP-MME), Atmos. Chem. Phys., 15, 335362, doi:10.5194/acp-15-335-2015, 2015.

Shindell, D. T., Lamarque, J.-F., Schulz, M., Flanner, M., Jiao, C., Chin, M., Young, P. J., Lee, Y. H., Rotstayn, L., Mahowald, N., Milly, G., Faluvegi, G., Balkanski, Y., Collins, W. J., Conley, A. J., Dalsoren, S., Easter, R., Ghan, S., Horowitz, L., Liu, X., Myhre, G., Nagashima, T., Naik, V., Rumbold, S. T., Skeie, R., Sudo, K., Szopa, S., Takemura, T., Voulgarakis, A., Yoon, J.-H., and Lo, F.: Radiative forcing in the ACCMIP historical and future climate simulations, Atmos. Chem. Phys., 13, 2939-2974, doi:10.5194/acp-13-2939-2013, 2013.

Szopa, S., Balkanski, Y., Schulz, M., Bekki, S., Cugnet, D., Fortems-Cheiney, A., Turquety, S., Cozic, A., Déandreis, C., Hauglustaine, D., Idelkadi, A., Lathière, J., Lefevre, F., Marchand, M., Vuolo, R., Yan, N., and Dufresne, J.-L.: Aerosol and ozone changes as forcing for climate evolution between 1850 and 2100, Clim. Dynam., 40, 2223-2250, doi:10.1007/s00382-0121408-y, 2012.

Tanré, D., Geleyn, J. F., and Slingo, J.: First results of the introduction of an advanced aerosol-radiation interaction in the ECMWF low resolution global model, in: Aerosols and Their Climatic Effects: Proceedings of the Meetings of Experts, Williamsburg, Virginia, 28-30 March 1983, edited by: Gerber, H. E. and Deepak, A., 133-177, Deepak, A., Hampton, Va., 1984.
Tanré, D., Kaufman, Y. J., Herman, M., and Mattoo, S.: Remote sensing of aerosol properties over oceans using the MODIS/EOS spectral radiances, J. Geophys. Res., 102, 16971-16988, 1997.

Taylor, K. E.: Summarizing multiple aspects of model performance in a single diagram, J. Geophys. Res., 106, 7183-7192, 2001.

Taylor, K. E., Stouffer, R. J., and Meehl, G: A summary of the CMIP5 experiment design, available at: http://cmip-pcmdi. llnl.gov/cmip5/docs/Taylor_CMIP5_design.pdf (last access: January 2011), 2009.

Textor, C., Schulz, M., Guibert, S., Kinne, S., Balkanski, Y., Bauer, S., Berntsen, T., Berglen, T., Boucher, O., Chin, M., Dentener, F., Diehl, T., Easter, R., Feichter, H., Fillmore, D., Ghan, S., Ginoux, P., Gong, S., Grini, A., Hendricks, J., Horowitz, L., Huang, P., Isaksen, I., Iversen, I., Kloster, S., Koch, D., Kirkevåg, A., Kristjansson, J. E., Krol, M., Lauer, A., Lamarque, J. F., Liu, X., Montanaro, V., Myhre, G., Penner, J., Pitari, G., Reddy, S., Seland, Ø, Stier, P., Takemura, T., and Tie, X.: Analysis and quantification of the diversities of aerosol life cycles within AeroCom, Atmos. Chem. Phys., 6, 1777-1813, doi:10.5194/acp-6-1777-2006, 2006.

Todd, M. C., Bou Karam, D., Cavazos, C., Bouet, C., Heinold, B., Baldasano, J. M., Cautenet, G., Koren, I., Perez, C., Solmon, F., Tegen, I., Tulet, P., Washington, R., and Zakey, A.: Quantifying uncertainty in estimates of mineral dust flux: An intercomparison of model performance over the Bodélé Depression, northern Chad, J. Geophys. Res., 113, D24107, doi:10.1029/2008JD010476, 2008.

Tosca, M. G., Randerson, J. T., and Zender, C. S.: Global impact of smoke aerosols from landscape fires on climate and the Hadley circulation, Atmos. Chem. Phys., 13, 5227-5241, doi:10.5194/acp-13-5227-2013, 2013.

Tsigaridis, K., Daskalakis, N., Kanakidou, M., Adams, P. J., Artaxo, P., Bahadur, R., Balkanski, Y., Bauer, S. E., Bellouin, N., Benedetti, A., Bergman, T., Berntsen, T. K., Beukes, J. P., Bian, H., Carslaw, K. S., Chin, M., Curci, G., Diehl, T., Easter, R. C., Ghan, S. J., Gong, S. L., Hodzic, A., Hoyle, C. R., Iversen, T., Jathar, S., Jimenez, J. L., Kaiser, J. W., Kirkevåg, A., Koch, D., Kokkola, H., Lee, Y. H, Lin, G., Liu, X., Luo, G., Ma, X., Mann, G. W., Mihalopoulos, N., Morcrette, J.-J., Müller, J.-F., Myhre, G., Myriokefalitakis, S., Ng, N. L., O’Donnell, D., Penner, J. E., Pozzoli, L., Pringle, K. J., Russell, L. M., Schulz, M., Sciare, J., Seland, Ø., Shindell, D. T., Sillman, S., Skeie, R. B., Spracklen, D., Stavrakou, T., Steenrod, S. D., Takemura, T., Tiitta, P., Tilmes, S., Tost, H., van Noije, T., van Zyl, P. G., von Salzen, K., Yu, F., Wang, Z., Wang, Z., Zaveri, R. A., Zhang, H., Zhang, K., Zhang, Q., and Zhang, X.: The AeroCom evaluation and intercomparison of organic aerosol in global models, Atmos. Chem. Phys., 14, 10845-10895, doi:10.5194/acp-1410845-2014, 2014.

Voldoire, A., Sanchez-Gomez, E., Salas y Mélia, D., Decharme, B., Cassou, C., Sénési, S., Valcke, S., Beau, I., Alias, A., Chevallier, M., Déqué, M., Deshayes, J., Douville, H., Fernandez, E., Madec, G., Maisonnave, E., Moine, M.-P., Planton, S., SaintMartin, D., Szopa, S., Tytéca, S., Alkama, R., Bélamari, S., Braun, A., Coquart, L., and Chauvin, F.: The CNRM-CM5.1 global climate model: description and basic evaluation, Clim. Dynam., 40, 2091-2121, doi:10.1007/s00382-011-1259-y, 2012. van Vuuren, D. P., Edmonds, J., Kainuma, M., Riahi, K., Thomson, A., Hibbard, K., Hurtt, G. C., Kram, T., Krey, V., Lamar- 
que, J. F., Masui, T., Meinshausen, M., Nakicenovic, N., Smith, S. J., and Rose, S. K.: The representative concentration pathways: an overview, Climatic Change, 109, 5-31, doi:10.1007/s10584-011-0148-z.

Zakey, A. S., Solmon, F., and Giorgi, F.: Implementation and testing of a desert dust module in a regional climate model, Atmos. Chem. Phys., 6, 4687-4704, doi:10.5194/acp-6-4687-2006, 2006.
Zhang, K., Wan, H., Liu, X., Ghan, S. J., Kooperman, G. J., Ma, P.-L., Rasch, P. J., Neubauer, D., and Lohmann, U.: Technical Note: On the use of nudging for aerosol-climate model intercomparison studies, Atmos. Chem. Phys., 14, 8631-8645, doi:10.5194/acp-14-8631-2014, 2014. 